\author{
Dr. sc. Duška Šarin, sutkinja \\ Ustavnog suda Republike Hrvatske
}

\title{
ASPEKTI PRAVA NA PRAVIČNO SUĐENJE - PRAVO NA PRISTUP SUDU KROZ JURISPRUDENCIJU USTAVNOG SUDA REPUBLIKE HRVATSKE
}

\author{
UDK: 342. 4. (497.5) \\ Pregledni rad \\ Primljeno: 1. 04. 2016.
}

\begin{abstract}
Ustavni sud Republike Hrvatske u svojoj praksi vezanoj uz zaštitu ljudskih prava i temeljnih sloboda, koja je u cijelosti usuglašena s praksom Europskog suda za ljudska prava, najviše se bavi povredom prava na pravično suđenje zajamčenog člankom 29. Ustava Republike Hrvatske. U radu se analizira dosadašnji razvitak jurisprudencije Ustavnog suda Republike Hrvatske kad je riječ o različitim aspektima prava na pravično suđenje s posebnim naglaskom na pravo na pristup sudu. Nakon određenja aspekata prava na pravično suđenje te „prava na sud“, analizira se pravo na pristup sudu odnosno njegovo ograničenje. Posebno se razmatraju postupovne pretpostavke za pristup sudu kao što su pravo podnošenja određene vrste zahtjeva sudu (dopuštenost podnošenja tužbe), pravo na pristup sudu kroz djelotvoran pravni lijek (jamstvo prava na žalbu i pravo na reviziju) te pravo na pristup sudu u određenim sudskim postupcima. Fokus je prvenstveno stavljen na odluke u kojima je Ustavni sud Republike Hrvatske utvrdio povrede navedenih prava zbog neprihvatljivih pravnih stajališta sudova.
\end{abstract}

Ključne riječi: Ustavni sud Republike Hrvatske, članak 29, stavak 1. Ustava, aspekti prava na pravično suđenje, pravo na pristup sudu

\section{UVODNE NAPOMENE}

Ustavom Republike Hrvatske ${ }^{1}$ (u daljnjem tekstu: Ustav) zajamčeno je pravo na pravično suđenje u članku 29, stavku 1., koji je sadržajno i širi od članka 6 ,

1 Ustav Republike Hrvatske donesen je na 10. skupnoj sjednici svih vijeća Sabora 21. prosinca 1990., te je proglašen na istoj sjednici drugog dana, dakle, 22. prosinca 1990. (v. Zapisnik 10. skupne sjednice svih vijeća Sabora, 4/2/JG i 27/5/SN), a objavljen je u Narodnim novinama broj 56/90. O tome v. Šarin, D.: Nastanak hrvatskoga Ustava, Narodne novine, Zagreb, 1997. Ustav je mijenjan i dopunjavan Ustavnim zakonom o izmjenama i dopunama Ustava Republike Hrvatske (Narodne novine broj 135/97. $\mathrm{i}$ 8/98. - pročišćeni tekst), Promjenom Ustava Republike Hrvatske (Narodne novine broj 113/00. i 124/00. pročišćeni tekst), Promjenom Ustava Republike Hrvatske (Narodne novine broj 28/01., 41/01. - pročišćeni tekst i 55/01. - ispravak pročišćenog teksta), Promjenom Ustava Republike Hrvatske (Narodne novine broj 76/10. i 85/10. - pročišćeni tekst), te Promjenom Ustava Republike Hrvatske (narodna ustavnotvorna inicijativa), (Narodne novine broj 5/14. - odluka Ustavnog suda broj: SuP-O-1/2014 od 14. siječnja 2014.). Poslije objave posljednjeg pročišćenog teksta Ustava (Narodne novine broj 85/10.), Ustavni sud Republike Hrvatske uputio je 23. ožujka 2011. Hrvatskom saboru izvješće broj: U-X-1435/2011 o ustavnopravno neprihvatljivim učincima pročišćenih tekstova Ustava Republike Hrvatske, ustavnih zakona, zakona, drugih propisa i općih akata (Narodne novine broj 37/11.). U tom su izvješću naznačeni 
Dr. sc. Duška Šarin: Aspekti prava na pravično suđenje - pravo na pristup sudu kroz jurisprudenciju... Zbornik radova Pravnog fakulteta u Splitu, god. 53, 3/2016., str. 729.-762.

stavka 1. Konvencije za zaštitu ljudskih prava i temeljnih sloboda Vijeća Europe (u daljnjem tekstu: Konvencija). ${ }^{2}$ Sadržaj ustavnog prava zajamčenog člankom 29, stavkom 1. Ustava ograničen je, dakle, na jamstva pravičnog suđenja. Sukladno tome, ocjenjujući navode ustavne tužbe sa stajališta tog ustavnog prava, Ustavni sud Republike Hrvatske (u daljnjem tekstu: Ustavni sud) ispituje eventualno postojanje povreda u postupcima pred sudovima i na temelju toga ocjenjuje je li postupak, razmatran kao jedinstvena cjelina, bio vođen na način koji je podnositelju osigurao pravično suđenje.

Rad se bavi dosadašnjim razvitkom jurisprudencije Ustavnog suda kad je riječ o različitim aspektima prava na pravično suđenje, a fokus je stavljen na pravo na pristup sudu jer je to osnovno pravo koje omogućuje korištenje ostalih jamstava propisanih člankom 29, stavkom 1. Ustava. Kada ne bi bilo jamstva prava na pristup sudu, značajke koje sudski postupak opisuju kao pošten i brz uopće ne bi imale nikakvu vrijednost ako sudski postupak ne bi započeo. Naime, budući da čitav sustav procesnih prava iz članka 29. Ustava počiva na ideji djelotvorne pravne zaštite, to je moguće samo u slučaju da ta zaštita bude i omogućena. ${ }^{3}$

Ustavni sud u dosadašnjoj je praksi štitio pravo na pristup sudu najviše zbog neprihvatljivih pravnih stajališta sudova. Naime, ustavno i konvencijsko pravo na pristup sudu, kao samostalno pravo, još uvijek nije u dostatnoj mjeri zaštićeno u praksi redovnih i specijaliziranih sudova. Iako Republika Hrvatska, zahvaljujući jurisprudenciji Ustavnog suda, danas gotovo da nema problema s Europskim sudom za ljudska prava u Strasbourgu (u daljnjem tekstu: Europski sud) ${ }^{4}$ kad je riječ o pravu na pristup sudu, u domaćoj sudskoj praksi to nije tako. Stoga se radom nastoji ukazati na pravna stajališta Ustavnog suda, koja su u cijelosti usuglašena

temeljni problemi koje su u strukturi ustavnog teksta prouzročili navedeni pročišćeni tekstovi. Budući da nadležni odbor Hrvatskog sabora do predaje rada nije objavio novi pročišćeni tekst Ustava, izrađen u skladu s izvješćem Ustavnog suda broj: U-X-1435/2011, u radu se za označavanje članaka Ustava koriste izvornici ustavnih tekstova (Narodne novine broj 56/90., 135/97., 113/00., 28/01., 76/10. i 5/14.).

2 Konvencija za zaštitu ljudskih prava i temeljnih sloboda usvojena je 4. studenoga 1950. u Rimu, a stupila je na snagu 3. rujna 1953. Nakon usvajanja Konvencije doneseno je 14 protokola, od kojih su neki dodali nova prava, a neki uređivali implementacijske mehanizme.

3 O raznim teorijama prava na pravnu zaštitu v. Triva, S., Dika, M.: Građansko parnično procesno pravo, VII. izdanje, Narodne novine d.d., Zagreb, 2004., str. 18-24.

4 Naime, Konvencijom odnosno Protokolom broj 11 uspostavljen je Europski sud koji je ovlašten donositi presude protiv država ugovornica ako one krše pravila Konvencije. Dakle, sve države koje su ratificirale Konvenciju, pa tako i Republika Hrvatska, dužne su priznati obvezatnost presude Europskog suda u predmetu u kojem su bile stranka. O obvezujućem učinku odluka Europskog suda v. Zupančić, B. M.: On the Interpretation of Legal Precedents and of the Judgements of the European Court of Human Rights, The Owl of Minerva, Essays on Human Rights, Eleven International Publishing, Utrecht, 2008, str. 351-392. O pravnoj naravi presuda Europskog suda v. De Salvia, M.: Execution of the Judgements of the European Court of Human Rights: Legal Nature of the Obligations of the States and European Supervision of National Legislative Choices, The Status of International Treaties on Human Rights, Venice Commission, Collection Science and technique of democracy, No. 42, Strasbourg: Council of Europe Publishing, September 2006.; Omejec, J.: Vijeće Europe i europska unija, institucionalni i pravni okviri, Novi informator, Zagreb, 2008. 
Dr. sc. Duška Šarin: Aspekti prava na pravično suđenje - pravo na pristup sudu kroz jurisprudenciju... Zbornik radova Pravnog fakulteta u Splitu, god. 53, 3/2016., str. 729.-762.

s praksom Europskog suda, kako bi se i na taj način doprinijelo što učinkovitijoj zaštiti ljudskog prava na pristup sudu u Republici Hrvatskoj. Nije, naime, dovoljno da se kršenja prava na pristup sudu a posteriori sankcioniraju na razini Ustavnog suda već taj problem treba rješavati a priori na onoj razini na kojoj on nastaje, što konkretno znači na razini sudstva. Cilj rada je, dakle, pridonijeti ne samo hrvatskoj znanosti ustavnog prava već i jurisprudenciji hrvatskih sudova.

\section{USTAVNI SUD REPUBLIKE HRVATSKE}

Iako Ustavni sud ima vrlo široke nadležnosti, posebno se ističe zaštita ljudskih prava i temeljnih sloboda zajamčenih Ustavom, ali i Konvencijom, ${ }^{5}$ koja se ostvaruje odlučivanjem o ustavnim tužbama podnesenima protiv tijela državne i javne vlasti. ${ }^{6}$

Ustavna je obveza Ustavnog suda zaštita ustavnih prava podnositelja ustavnih tužbi u slučajevima kad su ta prava povrijeđena presudom suda ili drugim pojedinačnim aktom nadležnog tijela državne ili javne vlasti. ${ }^{7}$ Ustaljeno je stajalište Ustavnog suda da je zadaća u prvom redu nadležnih tijela državne i javne vlasti da tumače i primjenjuju pravo. ${ }^{8}$ Uloga Ustavnog suda ograničena je na ispitivanje jesu li učinci takvog tumačenja odnosno primjene prava suglasni s Ustavom i jesu li u

5 Konvencija je stupila na snagu za Republiku Hrvatsku 5. studenoga 1997. na temelju Zakona o potvrđivanju Konvencije za zaštitu ljudskih prava i temeljnih sloboda i protokola br. 1, 4, 6, 7 i 11 Konvencije za zaštitu ljudskih prava i temeljnih sloboda, Narodne novine - Međunarodni ugovori, broj 18/97. Nakon stupanja na snagu Protokola br. 11 uz Konvenciju objavljen je i pročišćeni tekst Konvencije (Narodne novine - Međunarodni ugovori broj 6/99. - pročišćeni tekst i 8/99. - ispravak). Protokoli br. 12 i 13 uz Konvenciju potvrđeni su Zakonom o potvrđivanju Protokola br. 12 uz Konvenciju za zaštitu ljudskih prava i temeljnih sloboda, Narodne novine - Međunarodni ugovori broj 14/02. (Objava o stupanju na snagu Protokola br. 12 uz Konvenciju za zaštitu ljudskih prava i temeljnih sloboda, Narodne novine - Međunarodni ugovori broj 9/05.) i Zakonom o potvrđivanju Protokola br. 13 uz Konvenciju za zaštitu ljudskih prava i temeljnih sloboda, o ukidanju smrtne kazne u svim okolnostima, Narodne novine Međunarodni ugovori broj 14/02. (Objava o stupanju na snagu Protokola br. 13 uz Konvenciju za zaštitu ljudskih prava i temeljnih sloboda, Narodne novine - Međunarodni ugovori broj 13/03.). Hrvatska je ratificirala i Protokol br. 14 uz Konvenciju (Zakon o potvrđivanju Protokola br. 14 uz Konvenciju za zaštitu ljudskih prava i temeljnih sloboda, o izmjeni nadzornog sustava Konvencije, Narodne novine Međunarodni ugovori broj 1/06.).

6 V. članak 125. Ustava. Vrlo detaljno o ustrojstvu i djelovanju hrvatskog Ustavnog suda te rješenjima u poredbenom pravu v. Krapac, D.: Postupak pred Ustavnim sudom Republike Hrvatske ustrojstvo i proceduralni elementi ustavnog nadzora, Narodne novine, Zagreb, 2014.

7 O ustavnim osnovama odnosno pretpostavkama za podnošenje ustavne tužbe v. Belajec, V.: Ustavne osnove za podnošenje ustavne tužbe, Ustavni sud u zaštiti ljudskih prava - interpretativna uloga Ustavnog suda, Organizator, Zagreb, 2000., str. 97-113; Ljubić, D.: Ustavnosudska zaštita temeljnih ljudskih prava i sloboda - ustavna tužba (ustavna žalba), doktorska disertacija, Pravni fakultet Sveučilišta u Zagrebu, Zagreb, 2011.; Krapac, D: Pretpostavke za pokretanje i vođenje ustavnosudskog postupka zaštite individualnih ustavnih prava i sloboda: Pravni okviri i stvarne granice (,,procesnost “) hrvatskog modela ustavne tužbe, Hrvatsko ustavno sudovanje de lege lata i de lege ferenda, HAZU, Zagreb, 2009. Usp. Crnić, J.: Vladavina Ustava-zaštita sloboda i prava čovjeka i građanina ili kako pokrenuti postupak pred Ustavnim sudom Republike Hrvatske, Informator, Zagreb, 1994.

8 Pobliže o tome v. Sokol, S.: „Odnos Ustavnog suda i tijela sudbene vlasti“, Zbornik Pravnog fakulteta u Zagrebu, Zagreb, 2000., Vol. 50, No. 1-2, str. 55-64. 
konkretnom slučaju doveli do povrede ustavnih prava podnositelja ustavne tužbe. U postupcima pokrenutima ustavnom tužbom, Ustavni sud se u pravilu ne upušta u ispitivanje činjenica, jer njegova zadaća nije bavljenje pogreškama o činjenicama ili o pravu, osim ako i u mjeri u kojoj te pogreške mogu povrijediti ljudska prava i temeljne slobode zajamčene Ustavom. ${ }^{9}$

Ustavni sud se u svojoj praksi vezanoj uz zaštitu ljudskih prava i temeljnih sloboda najviše bavi pravom na pravično suđenje, baš kao i Europski sud čije visoke standarde zaštite ljudskih prava sve više implementira u svoje odluke i na taj način unosi u pravni poredak Republike Hrvatske. ${ }^{10}$

\section{PRAVO NA PRAVIČNO SUĐENJE}

Pravo na pravično suđenje jedno je od najvažnijih ljudskih prava, a zasigurno najvažnije procesno pravo. Ono se odnosi na zaštitu građanskih prava pojedinaca i to: kroz jamstvo prava na pravičnu i brzu raspravu kod utvrđivanja prava i obveza građanskopravne naravi pojedinaca ili kod odlučivanja o sumnji ili optužbi zbog kažnjivog djela. Pravo na pravično suđenje zajamčeno je člankom 29, stavkom 1. Ustava, kojim je propisano:

$$
\text { „Članak } 29 .
$$

Svatko ima pravo da zakonom ustanovljeni neovisni i nepristrani sud pravično i u razumnom roku odluči o njegovim pravima i obavezama, ili o sumnji ili optužbi zbog kažnjivog djela.

$$
(\ldots)^{\star}
$$

Kao što je navedeno, članak 29, stavak 1. Ustava sadržajno je širi od članka 6 , stavka 1. Konvencije koji glasi:

9 Svoje ovlasti u postupku u povodu ustavne tužbe Ustavni sud naveo je u odluci broj: U-III-1097/1999 od 13. ožujka 2000. (Narodne novine broj 38/00.). Više o ulozi Ustavnog suda u zaštiti ustavnih prava v. Šarin, D.: „Ustavni sud Republike Hrvatske kao institucionalni zaštitnik ljudskih prava i temeljnih sloboda“, Zbornik Pravnog fakulteta u Splitu, Split, 2015., god 52, br. 3, str. 755-784.

$10 \mathrm{O}$ međusobnom odnosu Europskog suda i Ustavnog suda te primjeni međunarodnog prava $\mathrm{v}$. Potočnjak, Ž., Stresec, M.: „Europski sud za ljudska prava i Ustavni sud Republike Hrvatske u zaštiti ljudskih prava“, Hrvatsko ustavno sudovanje - de lege lata i de lege ferenda, Hrvatska akademija znanosti i umjetnosti, Zagreb, 2009., str. 209-246; Rodin, S.: „Ustavni sud Republike Hrvatske i međunarodno pravo“, Zakonitost, časopis za pravnu teoriju i praksu, 1993., 47, broj 8/12, str. 578-587; Rodin, S.: „The Constitutional Court of the Republic of Croatia and International Law", Zetschrift für ausländisches öffentliches Recht und Völkerrecht (ZaöRV), Heidelberg Journal of International Law (HJIL), Max Planck - Institut für ausländisches öffentliches Recht und Völkerrecht, 1995., Vol. 3, str. 783-799; Šarin, D.: „Konvencija za zaštitu ljudskih prava i temeljnih sloboda kroz odnos Europskog suda za ljudska prava i Ustavnog suda Republike Hrvatske na primjeru zaštite ljudskog prava na pristup sudu“, Pravni vjesnik, Pravni fakultet u Osijeku, Osijek, 2014., god. 30, br. 3-4, str. 77-100. 
Dr. sc. Duška Šarin: Aspekti prava na pravično suđenje - pravo na pristup sudu kroz jurisprudenciju... Zbornik radova Pravnog fakulteta u Splitu, god. 53, 3/2016., str. 729.-762.

\section{„Članak 6.}

\section{PRAVO NA POŠTENO SUĐENJE}

1. Radi utvrđivanja svojih prava i obveza građanske naravi ili u slučaju podizanja optužnice za kazneno djelo protiv njega, svatko ima pravo da zakonom ustanovljeni neovisni i nepristrani sud pravično, javno i u razumnom roku ispita njegov slučaj. Presuda se mora izreći javno, ali se sredstva priopćavanja i javnost mogu isključiti iz cijele rasprave ili njezinog dijela zbog razloga koji su nužni u demokratskom društvu radi interesa morala, javnog reda ili državne sigurnosti, kad interesi maloljetnika ili privatnog života stranaka to traže, ili u opsegu koji je po mišljenju suda bezuvjetno potreban u posebnim okolnostima gdje bi javnost mogla biti štetna za interes pravde.

$$
(\ldots)^{\circ / 11}
$$

Valja podsjetiti da je Ustavom iz 1990. godine, ${ }^{12}$ člankom 29, alinejom 1. bilo propisano:

11 Članak 6, stavak 1. Konvencije u izvorniku na engleskom jeziku glasi:

"Article 6.

\section{RIGHT TO A FAIR TRIAL}

In the determination of his civil rights and obligations or of any criminal charge against him, everyone is entitled to a fair and public hearing within a reasonable time by an independent and impartial tribunal established by law. Judgement shall be pronounced publicly by the press and public may be excluded from all or part of the trial in the interest of morals, public order or national security in a democratic society, where the interests of juveniles or the protection of the private life of the parties so require, or the extent strictly necessary in the opinion of the court in special circumstances where publicity would prejudice the interests of justice."

Konvencija je objavljena na engleskom i hrvatskom jeziku u Narodnim novinama - Međunarodni ugovori broj 18/97. Usporedbom članka 6, stavka 1. Konvencije u izvorniku na engleskom jeziku i službenom prijevodu na hrvatski jezik vidljiva je nedosljednost prijevoda međunarodnih ugovora. Naime, u samom tekstu članka spominje se pravo na „pravično“ suđenje, dok se kao naslov članka 6. navodi: „Pravo na pošteno suđenje“. Razlog tome može biti i u teškoćama pri odgovarajućem tumačenju značenja engleske riječi „fair“ na hrvatski jezik. O teškoćama pri prevođenju više Uzelac, A.: „Hrvatsko procesno pravo i jamstvo pravičnog postupka iz Europske konvencije o zaštiti ljudskih prava“, Zbornik Pravnog fakulteta Sveučilišta u Rijeci, Rijeka, 1998., Vol. 19, Supplement, str. 1005-1030; Omejec, J.: Konvencija za zaštitu ljudskih prava i temeljnih sloboda u praksi Europskog suda za ljudska prava, Strasbourški acquis, Novi informator, Zagreb, 2013., str. 1121-1122.

12 V. bilj. 1. 
Dr. sc. Duška Šarin: Aspekti prava na pravično suđenje - pravo na pristup sudu kroz jurisprudenciju... Zbornik radova Pravnog fakulteta u Splitu, god. 53, 3/2016., str. 729.-762.

\author{
„Članak 29.
}

Svatko tko je osumnjičen ili optužen zbog kaznenog djela ima pravo:

- na pravično suđenje pred nadležnim sudom ustanovljenim zakonom;

$(\ldots)^{6}$

To je značilo da se navedeno jamstvo odnosi samo na suđenje u kaznenim postupcima, dok pravo na pravično suđenje u svim ostalim postupcima nije bilo zajamčeno Ustavom. ${ }^{13}$

Iako je današnji članak 29, stavak 1. Ustava nastao tek 2000. godine promjenom Ustava, ${ }^{14}$ Ustavni sud je i ranije u odlukama navodio svoje stajalište da pravo na pravično suđenje koje se jamči odredbom članka 29. Ustava ,valja protumačiti kao ustavno pravo građana na pravični postupak u svakoj vrsti postupaka pred upravnim tijelima i svim sudovima, a ne samo u kaznenim postupcima“. ${ }^{15}$

Promjenom Ustava iz 2000. godine ${ }^{16}$ izmijenjen je članak 29. Ustava, na način da je pravo na pravično suđenje, osim u kaznenim postupcima, utvrđeno kao ustavno jamstvo i u svim drugim pravnim postupcima u kojima se odlučuje o pravima i obvezama stanaka. Navedenom promjenom je, dakle, članak 29. Ustava sadržajno usklađen (u odnosu na neovisni i nepristrani sud te suđenje u razumnom roku) ${ }^{17}$ te

13 Ovdje treba naglasiti da je Ustavni sud, u skladu s „nadustavnom važnošću“ Konvencije (v. Sejdić i Finci protiv Bosne i Hercegovine (2009.), § 50.) neko vrijeme izravno primjenjivao odredbe članka 6, stavka 1. Konvencije na predmete u parničnim postupcima. O ustavnopravnim aspektima primjene Konvencije v. Rodin, S.: „Ustavnopravni aspekti primjene Europske konvencije za zaštitu ljudskih prava i temeljnih sloboda“, Zbornik Pravnog fakulteta u Zagrebu, Zagreb, 1998., Vol. 48, No. 1-2, str. 85-116.

14 Skrenimo pažnju da je to bilo nakon intervencije Ustavnog suda odlukom broj: U-I-745/1999 od 8. studenoga 2000. (Narodne novine broj 112/00. i www.usud.hr) kojom je pokrenuo postupak za ocjenu suglasnosti s ustavom te ukinuo pojedine članke Zakona o izvlaštenju (Narodne novine broj 9/94. i 35/94.). Naime, odlučivanje o prijedlogu podrazumijevalo je da Ustavni sud, između ostalog, odgovori i na pitanje „koje zahtjeve, jamstva i prava sadrži odredba iz stavka 1. članka 6. Konvencije glede postupka u kojem se odlučuje o građanskim pravima i obvezama“. Ustavni sud utvrdio je da iz navedene odredbe proizlaze za osobu o čijem se građanskom pravu ili obvezi odlučuje sljedeća postupovnopravna jamstva odnosno prava: pravo da o građanskom pravu odnosno obvezi odluči zakonom ustanovljen, neovisan i nepristran sud, pravo da postupak u kojem se odlučuje o građanskom pravu odnosno obvezi bude pravičan, pravo da postupak u pravilu bude javan i da odluka obvezatno bude javno objavljena, te pravo na donošenje odluke u razumnom roku.

15 V. odluke Ustavnog suda broj: U-III-39/1997 od 5. svibnja 1999. (Narodne novine broj 53/99. i www.usud.hr.); broj: U-III-32/1998 od 5. listopada 1999.; broj: U-III-523/2000 od 4. listopada 2000.; broj: U-I-673/1996 od 21. travnja 1999. (Narodne novine broj 39/99. i dr. i www.usud.hr). Usp. bilj. 13.

16 V. članak 10. Promjene Ustava Republike Hrvatske (Narodne novine broj 113/00.).

17 Valja podsjetiti da je javnost sudskog postupka (bila) zajamčena člankom 117. Ustava: „Sudske su rasprave javne i presude se izriču javno, u ime Republike Hrvatske. Javnost se može isključiti iz cijele rasprave ili njezina dijela zbog razloga koji su nužni u demokratskom društvu radi interesa morala, javnog reda ili državne sigurnosti, posebno ako se sudi maloljetnicima, ili radi zaštite privatnog života stranaka, ili u bračnim sporovima i postupcima u svezi sa skrbništvom i posvojenjem, ili radi čuvanja vojne, službene ili poslovne tajne i zaštite sigurnosti i obrane Republike Hrvatske, ali samo u opsegu koji 
čak i proširen u odnosu na članak 6. Konvencije. Naime, članak 29, stavak 1. Ustava ne ograničava se samo na „kaznene“ postupke te postupke o pravima i obvezama „građanske“ naravi, već se odnosi na sva „prava i obveze“, dakle i ona prava koja po praksi Europskog suda nisu obuhvaćena u članku 6, stavku 1. Konvencije.

Sadržaj ustavnog prava zajamčenog člankom 29, stavkom 1. Ustava ograničen je na jamstva pravičnog suđenja. Sukladno tome, ocjenjujući navode ustavne tužbe sa stajališta tog ustavnog prava, Ustavni sud, kao i Europski sud ${ }^{18}$ ispituje eventualno postojanje povreda u postupcima pred sudovima i na temelju toga ocjenjuje je li postupak, razmatran kao jedinstvena cjelina, bio vođen na način koji je podnositelju osigurao pravično suđenje. Pri tome neće svaka postupovna povreda dovesti do povrede ustavnog prava na pravično suđenje, već će to biti samo ona povreda koja je takvog značenja da podnositelju ugrožava pravo na pravično suđenje. ${ }^{19}$

\subsection{Aspekti prava na pravično suđenje prema jurisprudenciji Ustavnog suda Republike Hrvatske}

Jurisprudencija Ustavnog suda u odnosu na aspekte ili elemente prava na pravično suđenje sadržanog u članku 29, stavku 1. Ustava razvijala se sukladno razvoju i širenju prakse Europskog suda.

Pravo na pravično suđenje sastoji se, naime, od nekoliko elemenata: „prava na sud“, prava na pravično odlučivanje o pravima i obvezama ili o sumnji ili optužbi zbog kažnjivog djela te prava na odlučivanje u razumnom roku. Međutim, prema ustaljenoj praksi Ustavnog suda iz članka 29, stavka 1. Ustava proizlaze i brojna implicirana prava. ${ }^{20} \mathrm{Uz}$ pravo na pristup sudu, aspekti prava na pravično suđenje su:

je po mišljenju suda bezuvjetno potreban u posebnim okolnostima u kojima bi javnost mogla biti štetna za interese pravde."

18 V.Stromberg protiv Danske (2002.), odluka o dopuštenosti zahtjeva od 20. lipnja 2002. te Pedersen i Baadsgaard protiv Danske (2003.), odluka o dopuštenosti zahtjeva od 12. lipnja 2003.: ,Sud podsjeća da je njegova jedina uloga u odnosu na članak 6 . Konvencije da ispituje navodne postupovne povrede u postupcima pred domaćim sudovima te da na temelju toga, sagledavajući postupak kao jedinstvenu cjelinu, ocijeni je li postupak bio vođen na način koji podnositelju zahtjeva ugrožava pravo na pošteno suđenje."

19 Ustavni sud je još u odluci broj: U-III-2855/2003 od 23. prosinca 2004. (www.usud.hr) utvrdio: ,5. (...) Sadržaj ustavnog prava na pravično suđenje ograničen je na postupovna jamstva pravičnog suđenja pa Ustavni sud, ocjenjujući navode ustavne tužbe sa stajališta tog ustavnog prava, ispituje eventualno postojanje postupovnih povreda u postupcima pred sudovima te na temelju toga, sagledavajući postupak kao jedinstvenu cjelinu, ocjenjuje je li postupak bio vođen na način koji podnositelju osigurava pravično suđenje. (...).“ Istovjetan je pristup pravu na pravično suđenje Ustavni sud zauzeo, primjerice, u odluci broj: U-III-5423/2008 od 28. siječnja 2009 (Narodne novine broj 16/09. i www.usud.hr), odluci broj: U-III-1644/2006 od 29. listopada 2009. (www.usud.hr), te u brojim drugim odlukama.

20 Općenito o načelu impliciranih prava v. Omejec, J.: Konvencija za zaštitu ljudskih prava i temeljnih sloboda u praksi Europskog suda za ljudska prava, Strasbourški acquis, op. cit. u bilj. 11, str. 1032-1034. 
Dr. sc. Duška Šarin: Aspekti prava na pravično suđenje - pravo na pristup sudu kroz jurisprudenciju... Zbornik radova Pravnog fakulteta u Splitu, god. 53, 3/2016., str. 729.-762.

- pravo na procesnu ravnopravnost (equality of arms - ,jednakost oružja“),

- načelo kontradiktornosti,

- zabrana arbitrarnog postupanja,

- pravo na obrazloženu odluku,

- pravo na (učinkovito) pravno sredstvo,

- načelo vladavine prava i

- načelo pravne sigurnosti. ${ }^{21}$

Pored navedenog, u slučaju sumnje ili optužbe zbog kažnjivog djela osumnjičenik, okrivljenik ili optuženik ima i prava koja proizlaze iz ostalih stavaka članka 29. Ustava. ${ }^{22}$

\subsubsection{Pravo na procesnu ravnopravnosti (equality of arms - ,jednakost oružja")}

Ustavni sud smatra da zahtjevi načela pravičnog postupka uključuju način na koji se dokazi izvode i predlažu te ocjenu je li postupak u svojoj cjelini, uključujući i način na koji su dokazi predloženi i izvedeni, pravičan u smislu članka 29, stavka 1. Ustava i članka 6, stavka 1. Konvencije. Naime, značenje prava na „dobro pravosuđe“ i pravično suđenje u demokratskom društvu nužno uključuje jednakost sredstava stranaka u postupku, to jest obvezu suda da svakoj strani u postupku dade mogućnost iznošenja svojih razloga u uvjetima koji je ne stavljaju u položaj očite neravnopravnosti u odnosu na protivnu stranu.

21 O građanskopravnim aspektima prava na pravično suđenje v. Uzelac, A.: Hrvatsko procesno pravo i jamstvo ,pravičnog postupka“ iz Europske konvencije za zaštitu ljudskih prava i temeljnih sloboda, op. cit. u bilj. 11; Uzelac, A.: „Pravo na pravično suđenje u građanskim predmetima: Nova praksa Europskoga suda za ljudska prava i njen utjecaj na hrvatsko pravo i praksu“, Zbornik Pravnog fakulteta $u$ Zagrebu, Zagreb, 2010., Vol. 60, No. 1, str. 101-148; Grdinić, E.: „Pravo na pošteno suđenje u postupcima građanskopravne prirode zajamčeno čl. 6. st. 1. Europske konvencije za zaštitu ljudskih prava i temeljnih sloboda“, Hrvatska pravna revija, 2005. Vol. 5, br. 9, str. 7-16; Rozakis, C.: „The Right to a Fair Trial in Civil Cases“, Judicial Studies Institute Journal, Judicial Studies Institute Dublin, 2004., Vol. 4, No. 2, str. 96-106; Iličić Topolovec, S.: Pravičan postupak iz članka 6. stavka 1. Europske konvencije za zaštitu ljudskih prava i temeljnih sloboda-građanskopravni aspekt, magistarski rad, Pravni fakultet Sveučilišta u Zagrebu, Zagreb, 2006.

22 Više o kaznenopravnim aspektima prava na pravično suđenje v. Pavišić, B.: Kazneno pravo Vijeća Europe, Golden marketing, Zagreb, 2006.; Krapac, D.: Kazneno procesno pravo, Prva knjiga: Institucije, IV. izdanje, Narodne novine d.d., Zagreb, 2010., str. 137-170; Grdinić, E.: „Opće jamstvo poštenog suđenja u kaznenim postupcima i presumpcija nedužnosti prema članku 6. stavcima 1. i 2. Konvencije za zaštitu ljudskih prava i temeljnih sloboda“, Hrvatska pravna revija, 2006., Vol. 6, br. 1, str. 7-17; Mahoney, P.. ,"Right to a Fair Trial in Criminal Matters under Article 6 E.C.H.R“, Judicial Studies Institute Journal, Judicial Studies Institute Dublin, 2004., Vol. 4, No. 2, str. 107-129; Ritossa, D.: „Elementi modela crime control i due process u odlukama tijela Europske konvencije za zaštitu ljudskih prava i temeljnih sloboda s obzirom na članak 6. stavak 1. Europske konvencije za zaštitu ljudskih prava i temeljnih sloboda“, Hrvatski ljetopis za kazneno pravo i praksu, Hrvatsko udruženje za kaznene znanosti i praksu, Zagreb, 2003., Vol. 10, br. 1, str. 75-107. 
Stoga je prema praksi Ustavnog suda, sukladno jurisprudenciji Europskog suda, jedan od aspekata prava na pravično suđenje i pravo na procesnu ravnopravnost (equality of arms - ,jednakost oružja“), koje je sadržajno blisko načelu saslušanja stranaka u domaćem pravu. ${ }^{23}$ Prema tom načelu, svaka od stranaka treba imati „razumnu mogućnost da u postupku brani svoja prava pod uvjetima koji ju ne stavljaju u bitno nepovoljniji položaj u odnosu na njenog protivnika““. ${ }^{24}$ Iz prava na jednakost oružja izvode se i pojedina prava u odnosu na izbor i izvođenje dokaza. ${ }^{25}$

Ustavni sud, naime, smatra da načelo jednakosti sredstava, u smislu pravične ravnoteže među strankama (fair balance), nužno obuhvaća razumnu mogućnost stranaka da izlože činjenice i podupru ih svojim dokazima na način da, kao što je navedeno, niti jednu od stranaka ne stavljaju u bitno lošiji položaj u odnosu na suprotnu stranku. ${ }^{26} \mathrm{Da}$ bi se to spriječilo, postupak mora biti kontradiktoran, jer samo kontradiktoran postupak daje strankama mogućnost uvida te izražavanja svog mišljenja o stajalištima ili dokazima koje predlaže suprotna stranka.

\subsubsection{Načelo kontradiktornosti}

Važan dio jamstva pravičnog postupka, na koji Ustavni sud u svojim odlukama upozorava, jest i spomenuto načelo kontradiktornosti. ${ }^{27}$ Upravo zbog povrede ovog aspekta pravičnosti postupka, Europski sud je u predmetu Maravić Markěs protiv Hrvatske (2014.) utvrdio (između ostalih) i povredu članka 6, stavka 1. Konvencije, ${ }^{28}$ kao što je to prethodno učinio i u predmetu Vanjak protiv Hrvatske

23 V., primjerice, odluku Ustavnog suda broj: U-III-4609/2013 od 10. rujna 2014. (www.usud.hr).

24 Usp. praksu Europskog suda, primjerice, predmet Kaufman protiv Belgije (1986.), predmet Perić protiv Hrvatske (2008.).

25 V. odluke Ustavnog suda broj: U-III-745/2009 od 1. travnja 2010. (Narodne novine broj 50/10. i www.usud.hr); broj: U-III-3874/2008 od 4. travnja 2012. (www.usud.hr); broj: U-III-2182/2014 od 17. lipnja 2014. (Narodne novine broj 108/14. i www.usud.hr); broj: U-III-3580/2012 od 3. lipnja 2015. (www.usud.hr); broj: U-III-2917/2015 od 20. siječnja 2016. (www.usud.hr).

${ }_{26}$ Ustavni sud je na početku utvrđivanja povrede prava na procesnu ravnopravnost samo navodio da je povrijeđeno ,načelo jednakosti sredstava“ koje na raspolaganju moraju imati obje stranke bez obrazlaganja što to načelo konkretno znači. Naime, Ustavni sud navodio je da je to načelo samo ,jedan izraz pojma pravičnog suđenja koji uključuje i temeljno pravo stranke da postupak bude kontradiktoran." V. odluku Ustavnog suda broj: U-III-2028/2002 od 8. srpnja 2004. (Narodne novine broj 101/04. i www. usud.hr).

27 Ustavni sud je kao i kod prava na jednakost oružja i kod načela kontradiktornosti na počecima utvrđivanja povrede navodio samo da je, odnosno nije, povrijeđeno načelo kontradiktornosti bez definiranja što ono konkretno znači. V. odluku Ustavnog suda broj: U-III-766/2000 od 13. prosinca 2000. (Narodne novine broj 131/00. i 3/01.-ispr.).

28 Naime, Europski sud je u predmetu Maravić Markeš protiv Hrvatske (2014.), § 56. naveo: „Iz toga slijedi da u ovom slučaju poštovanje prava na pošteno suđenje, zajamčeno člankom 6. stavkom 1 . Konvencije, zahtijeva da se podnositeljici zahtjeva da prilika da se upozna s odgovorom koji je dostavila suprotna strana i da na njega da primjedbe ... Međutim, podnositeljica zahtjeva nije dobila takvu priliku. Taj nedostatak nije ispravljen ni činjenicom da je podnositeljica zahtjeva mogla podnijeti i jest podnijela ustavnu tužbu Ustavnom sudu, budući da taj sud ne provodi cjelovito preispitivanje predmeta.“ 
(2010.) u kojem je izrazio stajalište da se „mora poštovati pravo na kontradiktornost postupka. To pravo u načelu znači da strankama u sudskom postupku koji potpada pod domašaj članka 6. treba omogućiti da saznaju za sve predložene dokaze ili iznesena očitovanja, te da na njih podnesu svoje primjedbe“. ${ }^{29}$

Stoga Ustavni sud u odlukama navodi da je stajališta da, načelno, nedostavljanje strankama podnesaka koji su sudu tijekom postupka dostavljeni predstavlja propust suda i takvo postupanje u suprotnosti je s obvezom suda da u provedbi načela kontradiktornosti strankama dostavi isprave i dokaze pribavljene radi utjecaja na odluku suda i omogući strankama očitovanje na njih.

Ustavni sud, međutim, napominje da nije na njemu procjenjivati mora li se svaki podnesak jedne stranke dostavljati protivnoj stranci, jesu li u njemu iznesene činjenice ili okolnosti važne za meritum spora. To je u prvom redu zadaća sudova koji najbolje poznaju činjenice predmeta. ${ }^{30}$ Dakle, Ustavni sud smatra da ne mora svaki propust suda da dostavi strankama pribavljenu ispravu ili dokaz dovesti do povrede ustavnog prava na pravično suđenje, a što sve uvijek ovisi o okolnostima konkretnog slučaja. ${ }^{31}$

\subsubsection{Zabrana arbitrarnog postupanja}

Prema jurisprudenciji Ustavnog suda ustavno pravo na pravično suđenje jamči zaštitu od arbitrarnosti u odlučivanju sudova i drugih državnih tijela. Obrazloženja sudskih odluka odnosno odluka drugih nadležnih tijela koja ne sadrže ozbiljne, relevantne i dostatne razloge za ocjenu kakva je odlukom dana, upućuju na zaključak o arbitrarnosti u postupovnom i/ili materijalnopravnom smislu. ${ }^{32}$

Međutim, u svojim odlukama Ustavni sud naglašava da je primarna zadaća redovnih sudova, a ne Ustavnog suda, tumačiti i primjenjivati pravo na konkretne sudske predmete. U načelu i bez utjecaja na ovlast da ispituje suglasnost sudskih odluka s Ustavom, uloga Ustavnog suda nije da sam procjenjuje činjenice koje su vodile nadležne redovne sudove da donesu jednu odluku, a ne drugu. Zadaća Ustavnog suda nije ni da se bavi pogreškama o činjenicama ili pravu koje je

29 V. Vanjak protiv Hrvatske (2010.), § 52.

30 Primjerice, Ustavni sud je u odluci broj: U-III-6296/2013 od 6. ožujka 2014. (Narodne novine broj 36/14. i www.usud.hr) naveo: „Ustavni sud prihvaća i ocjenu Upravnog suda da načelo učinkovitog vođenja postupka podrazumijeva da se upravni postupak mora voditi bez nepotrebnog odugovlačenja $\mathrm{i}$ odgađanja ročišta, što može uključivati i neostavljanje dodatnog roka za očitovanje na podneske koji po svojem sadržaju ne sadrže podatke važne za donošenje odluke o sporu ili o kojima se protivna stranka već imala prilike očitovati."

${ }_{31}$ V. odluke Ustavnog suda broj: U-III-815/2013 od 8. svibnja 2014. (www.usud.hr); broj: U-III-2344/2014 od 15. listopada 2014. (www.usud.hr).

32 V. primjerice, odluku Ustavnog suda broj: U-III-38107/2009, U-III-41630/2009 od 10. rujna 2013. (Narodne novine broj 122/13. i www.usud.hr). 
Dr. sc. Duška Šarin: Aspekti prava na pravično suđenje - pravo na pristup sudu kroz jurisprudenciju... Zbornik radova Pravnog fakulteta u Splitu, god. 53, 3/2016., str. 729.-762.

navodno počinio redovni odnosno specijalizirani sud, osim ako i u mjeri u kojoj one mogu povrijediti ljudska prava i temeljne slobode zaštićene Ustavom. Naime, Ustavni sud je stajališta da sudska interpretacija činjenica, okolnosti i događaja mora biti takva da ne ostavlja nikakve dvojbe je li sud svoju pažnju usmjerio na pitanja koja je bio obvezan razmotriti i je li isključio pitanja koja su irelevantna za ono što je u konkretnom predmetu morao razmotriti. ${ }^{33}$ Navedeno stajalište odnosi se i na upravna tijela kad pri rješavanju o pravima i obvezama u upravnim stvarima neposredno primjenjuju zakone i druge propise. ${ }^{34}$

Ustavni sud u tom smislu u odlukama ponavlja da nije njegova zadaća preuzeti ulogu viših sudova, koji su prvi pozvani rješavati probleme tumačenja domaćeg prava. Kad bi bilo tako, Ustavni sud djelovao bi kao sud trećeg ili četvrtog stupnja i ne bi poštovao ustavna ograničenja koja su nametnuta njegovu djelovanju. Stoga je zadaća Ustavnog suda ograničena na ispitivanje jesu li učinci takve interpretacije sudova suglasni s Ustavom s aspekta zaštite ljudskih prava i temeljnih sloboda. ${ }^{35}$

33 V. odluke Ustavnog suda broj: U-III-5807/2010 od 30. travnja 2013. (www.usud.hr); broj: U-III-4335/2010 od 10. rujna 2013. (www.usud.hr).

34 V., primjerice, odluku Ustavnog suda broj: U-III-4614/2010 od 18. rujna 2013. (www.usud.hr) u kojoj je navedeno da se u tom ,ustavnosudskom postupku, u granicama svoje nadležnosti, Ustavni sud mora ograničiti na ispitivanje jesu li osporeni pojedinačni akti arbitrarni, pri čemu se postupanje nadležnih tijela neće smatrati arbitrarnim ako su nadležna tijela za svoje odluke imala valjanu pravnu osnovu, ako su u provedenim postupcima uspjela utvrditi i u odlukama predočiti relevantne, dostatne i uvjerljive razloge za svoju ocjenu..., odnosno ako te odluke nisu ni na koji drugi način očito nerazumne“. Usp. odluku Ustavnog suda broj: U-III-4818/2015 od 28. siječnja 2016. (www.usud.hr).

35 Ustavni sud je, primjerice, u odluci broj: U-III-3874/2008 od 4. travnja 2012. (www.usud.hr) usvojio ustavnu tužbu podnositelja zbog arbitrarnosti odluka nadležnih sudova, navodeći: ,7.2. ... Dakle, prvostupanjski sud je u ponovljenom postupku, ne poštivajući uputu drugostupanjskog suda, na temelju istog činjeničnog stanja kao onog utvrđenog prije ukidnog drugostupanjskog rješenja, donio dijametralno suprotnu odluku o tužbenom zahtjevu od one odluke donesene u postupku prije ukidnog rješenja, a da za svoje razloge zašto je sada drugačije odlučio nije pružio valjano obrazloženje“. U odluci broj: U-III-2182/2014 od 17. lipnja 2014. (Narodne novine broj 108/14. i www.usud.hr) Ustavni sud utvrdio je povredu prava na pravično suđenje zbog arbitrarnosti postupanja i odlučivanja sudova: ,9.3. Ustavni sud u prethodno navedenom kontekstu također ocjenjuje da sudovi moraju imati jednak pristup vjerodostojnosti dokaza opterećenih istovrsnim prigovorima stranaka (u konkretnom slučaju prigovora prethodnog privatnog angažmana vještaka odnosno stručnog svjedoka u stvari). Dijametralno suprotno tretiranje takvih dokaza (...), a da za to nije pruženo valjano obrazloženje, po ocjeni Ustavnog suda sadrži bitne nedostatke u obrazlaganju zauzetih pravnih stajališta i upućuje na zaključak o arbitrarnosti tako donesenih odluka u postupovnom i/ili materijalnopravnom smislu. Ustavni sud stoga ocjenjuje da sudovi i zbog tog razloga nisu proveli postupak, donijeli odluke i obrazložili svoja pravna stajališta na način koji bi otklonio sumnju u arbitrarnost postupanja i odlučivanja, odnosno na način koji bi činio nedvojbenim utemeljenost donesenih odluka na ustavnopravno prihvatljivom tumačenju i primjeni mjerodavnog postupovnog $\mathrm{i}$ materijalnog prava, čime je također došlo do povrede prava podnositelja na pravično suđenje, zajamčeno člankom 29. stavkom 1. Ustava.“ 


\subsubsection{Pravo na obrazloženu sudsku odluku i pravo na (učinkovito) pravno sredstvo}

Ustavni sud u svojim odlukama ističe da „Ustav jamči stranci u postupku pravo na obrazloženu odluku tijela upravne odnosno sudske vlasti, kao i pravo na (učinkovito) pravno sredstvo, a oba navedena prava međusobno su usko povezana, proizlaze jedno iz drugog i čine neodvojive sastavnice prava na pravično suđenje (odlučivanje) zajamčenog člankom 29. stavkom 1. Ustava. “36

Pravo na obrazloženu sudsku odluku podrazumijeva pozitivnu obvezu sudova da u svojim presudama navedu razloge kojima su se vodili pri njihovom donošenju. Međutim, eventualna povreda prava na pravično suđenje zbog propusta suda da se te obveze pridržavaju uvijek će ovisiti o osobitim okolnostima svakog konkretnog slučaja. Ta obveza, sukladno jurisprudenciji Ustavnog suda, postoji i izvire i iz članka 6, stavka 1. Konvencije. ${ }^{37}$

Ipak, pravo na obrazloženu sudsku odluku i pravo na (učinkovito) pravno sredstvo Ustavni sud je prije nego što je o njima počeo odlučivati s aspekta članka 29 , stavka 1. Ustava, štitio u okviru članka 18. Ustava. Naime, Ustavni sud navodio je da osporeno rješenje ili odluka ne sadrže elemente propisane zakonom odnosno da nisu obrazloženi na način koji bi osiguravao ostvarenje ustavnog jamstva prava na žalbu, budući da to jamstvo ne podrazumijeva samo mogućnost pukog izjavljivanja žalbe u njezinom formalnopravnom smislu, već mogućnost iznošenja argumentiranih žalbenih razloga koji će povećati izglede žalitelja da sa svojom žalbom uspije u žalbenom postupku. ${ }^{38}$

36 V. primjerice, recentniju odluku Ustavnog suda broj: U-III-296/2014 od 17. srpnja 2015. (www. usud.hr) i odluku broj: U-III-4809/2010 od 20. ožujka 2014. (www.usud.hr).

37 V. odluku Ustavnog suda broj: U-III-4618/2012 od 2. studenoga 2015. (www.usud.hr) u kojoj se Ustavni sud pozvao na opća pravna stajališta Europskog suda u odnosu na prigovor podnositelja da postupak nije bio pravičan jer presuda nije bila valjano obrazložena, navedena u presudi Gorou protiv Grčke (2009.): „37. Sud ponavlja da članak 6. stavak 1. Konvencije obvezuje sudove da daju razloge za svoje odluke, ali on se ne smije shvatiti kao da zahtijeva detaljan odgovor na svaki argument. Stupanj do kojeg se ta dužnost primjenjuje može varirati sukladno prirodi odluke. Štoviše, nužno je uzeti u obzir, inter alia, različitost prijedloga (submissions) koje parničar može podastrijeti sudovima i različitost koja postoji u državama ugovornicama kad je riječ o zakonskim odredbama, običajnim pravilima, pravnom mišljenju te prezentaciji i pripremi nacrta presuda. To su razlozi zbog kojih o pitanju jesu li sudovi propustili ispuniti obvezu iznošenja razloga koji izvire iz članka 6. stavka 1. može biti odlučeno u svjetlu okolnosti slučaja (vidi među ostalim izvorima, Ruiz Torija protiv Španjolske, 9. prosinca 1994., § 29., i Van de Hurk protiv Nizozemske, 19. travnja 1994., § 61....).“

38 V. odluke Ustavnog suda broj: U-III-660/1998 od 20. siječnja 1999. (Narodne novine broj 10/99. i 20/99. - ispr. i www.usud.hr); broj: U-III-491/2000 od 6. lipnja 2000. (Narodne novine broj 60/00. i 67/00. - ispr. i www.usud.hr); broj: U-III-548/1998 od 29. lipnja 2001. (Narodne novine broj 63/01. i www.usud.hr). Valja napomenuti da je Ustavni sud još odlukom broj: U-I-206/1992 i dr. od 8. prosinca 1993. (Narodne novine broj 49/93., 57/93. i 113/93. i www.usud.hr) ukinuo stavak 3, članka 26. Zakona o hrvatskom državljanstvu (Narodne novine broj 53/91. i 28/92.) kojim je bilo određeno da „u obrazloženju rješenja o odbijanju zahtjeva za stjecanje državljanstva ne moraju biti navedeni razlozi za odbijanje zahtjeva“. Naime, Ustavni sud smatrao je da rješenje bez obrazloženja, odnosno rješenje koje ne sadrži ni utvrđene činjenice, ni pravne propise ni razloge zbog kojih nije uvažen zahtjev stranke, teško da može 
Dr. sc. Duška Šarin: Aspekti prava na pravično suđenje - pravo na pristup sudu kroz jurisprudenciju... Zbornik radova Pravnog fakulteta u Splitu, god. 53, 3/2016., str. 729.-762.

Spomenimo još i to da je Ustavni sud odlučivao o povredi prava na (učinkovito) pravno sredstvo i u smislu članka 13. Konvencije, a vezano za postupke izvršenja presuda Europskog suda. ${ }^{39}$

\subsubsection{Načelo vladavine prava i načelo pravne sigurnosti}

Postupci pred sudovima moraju biti u skladu s vladavinom prava, koja se može poistovjetiti i s dobrim radom pravosuđa pa bi prava, zajamčena Ustavom i međunarodnim pravnim aktima, koja obvezuju Republiku Hrvatsku, bila teorijska i prividna, a ne stvarna i djelotvorna kad ne bi postojala obveza sudbene vlasti da u postupku primijeni sva postupovna i materijalnopravna jamstva pravičnog suđenja, koja su u tom smislu i propisana. ${ }^{40}$

Ustavni sud, ustvari, smatra da se sudski postupci moraju provesti sukladno ustavnom načelu vladavine prava kao najviše vrednote ustavnog poretka Republike Hrvatske i temelja za tumačenje Ustava. ${ }^{41}$ Pored toga, Ustavni sud ističe da vladavina prava sadrži obvezu sudova da, u slučajevima kada tumače i primjenjuju propise, postupaju na način da jamče poštovanje ljudskih prava i temeljnih sloboda zajamčenih Ustavom. ${ }^{42}$ Provođenje sudskih postupaka ne smije se izjednačiti samo

biti valjana podloga za djelotvoran pravni lijek. I odlukom broj: U-I-248/1994 od 13. studenoga 1996. (Narodne novine broj 103/96. i www.usud.hr) Ustavni sud ukinuo je pojedine odredbe članka 209. Zakona o općem upravnom postupku (Narodne novine broj 53/91.), utvrdivši da su te odredbe protivne Ustavu iz razloga što se pravo na žalbu, odnosno pravo na drugu pravnu zaštitu može učinkovito ostvarivati samo ako tijelo koje je donijelo rješenje navede razloge kojima se vodilo pri donošenju rješenja, a koji se onda mogu pobijati u obrani žaliteljevih prava i na zakonu zasnovanih interesa.

39 Naime, Ustavni sud je u odluci broj: U-III-334/2013 od 30. siječnja 2014. (Narodne novine broj 25/14. i www.usud.hr), kao i u odluci broj: U-III-2306/2013 od 18. veljače 2014. (Narodne novine broj 29/14. i www.usud.hr) ocjenjivao je li dostupno pravno sredstvo (zahtjev za izmjenu domaće kaznene presude) bilo djelotvorno u podnositeljevu slučaju te zaključio da je unatoč tome što nema razloga sumnjati u njegovu načelnu djelotvornost, u konkretnom slučaju to pravno sredstvo ,podbacilo“.

40 V., primjerice, odluku Ustavnog suda broj: U-III-2494/2008 od 30. ožujka 2011. (www.usud.hr). Potrebno je podsjetiti da i Europski sud opetovano naglašava važnost članka 6, stavka 1. Konvencije. Tako je u predmetu Perez protiv Francuske (2004.), § 64. istaknuto: „U tom smislu Sud primjećuje da pravo na pošteno suđenje ima tako važno mjesto u demokratskom društvu da ne može biti nikakvog opravdanja za restriktivno tumačenje članka 6 . stavka $1 . “$

${ }^{4}$ Ustav je u članku 3. utvrdio koje su ,najviše vrednote ustavnog poretka“ Republike Hrvatske, a jedna od njih je i vladavina prava (rule of law), kao ideal ideje ustavne vladavine. Dakle, sustava političke vlasti koji bi bio utemeljen na poštovanju ustava, zakona i drugih propisa. O najvišim vrednotama ustavnog poretka Republike Hrvatske v. Bačić, A: „Ustav Republike Hrvatske i najviše vrednote ustavnog poretka“, Zbornik radova Pravnog fakulteta u Splitu (Online), 2012,. Vol. 49, br. 1, str. 1-21, http://www. pravst.unist.hr/dokumenti/zbornik/2012103/zb201201_001.pdf. O vladavini prava v. Smerdel, B., Sokol, S.: Ustavno pravo, IV. izdanje, Narodne novine d.d., Zagreb, 2009., str. 48-49; Sokol, S.: „Ustavni sud Republike Hrvatske u zaštiti i promicanju vladavine prava“, Ustav kao jamac načela pravne države, Organizator, Zagreb, 2002., str. 24.

42 Istovjetno stajalište u odnosu na članak 6, stavak 1. Konvencije zastupa i Europski sud. Taj članak, naime, sadrži temeljno načelo vladavine prava, što je Europski sud izrekao još u predmetu Golder protiv Ujedinjenog Kraljevstva (1975.), smatrajući da pri tumačenju članka 6. Konvencije, u svjetlu cilja i svrhe Konvencije, treba poći od vladavine prava. (v. §34. presude). Navedeno stajalište Europski sud potvrdio je i u predmetu Salabiaku protiv Francuske (1988.), istaknuvši da je cilj i svrha članka 6. Konvencije, 
sa zahtjevom za zakonitošću postupanja tijela državne vlasti, već mora uključiti zahtjev prema kojemu zakonske posljedice moraju biti primjerene legitimnim očekivanjima stranaka u svakom konkretnom slučaju. ${ }^{43}$

Pravila koja propisuju formalne pretpostavke koje treba zadovoljiti pri korištenju nekog pravnog sredstva posebno su usmjerena na osiguravanje pravne sigurnosti kao jedne od temeljnih sastavnica vladavine prava. Potrebno je jasno, precizno i svima dostupno zakonsko postupovno pravilo s predvidljivim posljedicama za one na koje se primjenjuje.

Ustavni sud, dakle, smatra da pravo na pravično suđenje uvijek mora biti tumačeno u svjetlu vladavine prava kojoj je načelo pravne sigurnosti jedan od temeljnih aspekata: ono zahtijeva da sve stranke imaju djelotvorno pravno sredstvo pred domaćim sudovima koje im omogućuje da brane svoja prava. ${ }^{44}$

U skladu s tim, Ustavni sud u odlukama opetovano ističe da je jedno od temeljnih vidova vladavine prava načelo pravne sigurnosti koje je implicitno sadržano u Ustavu i Konvenciji. Ustavni sud, naime, smatra da je načelo pravne sigurnosti inherentno pravu na pravično suđenje u smislu članka 29, stavka 1. Ustava i članka 6, stavka 1. Konvencije. ${ }^{45}$ Budući da je još uvijek najčešći problem u sudskom sustavu uz koji se vezuje načelo pravne sigurnosti problem neujednačene sudske prakse $u$ istovrsnim sudskim stvarima, Ustavni sud smatrao je potrebnim ponoviti i u recentnijoj odluci opća pravna načela (prethodno navedena) na kojima Europski sud temelji ocjenu o povredi članka 6 . Konvencije u slučajevima kada se utvrdi postojanje neujednačene sudske prakse među različitim sudovima ili različitim jurisdikcijama, odnosno postojanje oprečnih odluka koje je donio isti sud u usporedivim postupcima. ${ }^{46}$

koji štiti pravo na pravično suđenje, jamčenje elementarnog načela vladavine prava. (v. § 28. presude). Europski sud, dakle, zahtijeva od država ugovornica da sudske postupke provode poštujući načelo vladavine prava.

43 V. odluke Ustavnog suda broj: U-III-1112/2001 od 19. veljače 2004. (Narodne novine broj 27/04. i www.usud.hr); broj: U-III-350/2007 od 9. ožujka 2011. (Narodne novine broj 36/11. i www.usud.hr). Valja napomenuti da je prethodno Ustavni sud samo utvrđivao da je „osporena odluka protivna ustavnom načelu vladavine prava (članak 3. Ustava)“ bez povezivanja sa člankom 29, stavkom 1. Ustava. V. odluku Ustavnog suda broj: U-III-1027/1998 od 26. siječnja 2001. (Narodne novine broj 12/01. i 18/01.-ispr. i www.usud.hr).

${ }^{44}$ O tome v. odluke Ustavnog suda broj: U-III-6064/2011 od 28. studenoga 2012. (www.usud.hr); broj: U-III-2114/2009 od 14. veljače 2013. (Narodne novine broj 27/13. i www.usud.hr).

45 V., primjerice, odluke Ustavnog suda broj: U-III-5163/2011 od 11. prosinca 2014. (www.usud. hr); broj: U-III-3794/2015 od 15. ožujka 2016. (www.usud.hr) te odluku Europskog suda Vusić protiv Hrvatske (2010.), § 44.

46 V. odluku Ustavnog suda broj: U-III-4150/2010 i dr. od 12. siječnja 2015., točke od 129. do 134. (Narodne novine broj 6/15. i www.usud.hr). Naime, Ustavni sud prihvatio je načelna pravna stajališta koja je Europski sud utvrdio u predmetu Nejdat Şahin i Perihan Şahin protiv Turske (2011.), §§ 49-59. 
Na koncu ovog dijela rada može se zaključiti da se različiti aspekti prava na pravično suđenje međusobno prožimaju te Ustavni sud u svojim odlukama često utvrđuje povredu članka 29, stavka 1. Ustava zbog istovremenog nepoštovanja više aspekata prava na pravično suđenje.

\section{4. ,PRAVO NA SUD“}

„Pravo na sud“, za razliku od prethodno navedenih impliciranih prava, izrijekom je zajamčeno člankom 29, stavkom 1. Ustava u kojem je propisano da „svatko ima pravo da zakonom ustanovljeni, neovisni i nepristrani sud ... odluči ...". Konkretno, to znači da taj članak jamči:

- pravo na zakonom ustanovljeni sud,

- pravo na neovisni sud i

- pravo na nepristrani sud.

Može se, dakle, reći da se nekoliko zahtjeva pravičnog suđenja odnosi na svojstva tijela koje provodi postupak i donosi odluku. No, Ustavni sud prvenstveno se bavi povredom prava na neovisni i nepristrani sud te je u tom smislu prihvatio mjerila Europskog suda. ${ }^{47}$

Sukladno tome, neovisnost suda u prvom redu znači njegovu neovisnost o izvršnoj vlasti i strankama. Naime, kod ispitivanja može li se neko tijelo smatrati neovisnim, mora se, između ostalog, obratiti pažnja na način biranja članova tog tijela, duljinu trajanja njihova mandata i postojanje jamstva protiv vanjskih pritisaka. Pored toga mora se uzeti u obzir i pitanje odaje li takvo tijelo vanjski dojam neovisnosti.

Zahtjev za nepristranošću suca djelomično se preklapa sa zahtjevom za neovisnošću suda, osobito kad je riječ o zabrani utjecaja političkih stranaka i tijela državne i javne vlasti na suđenje. Ipak, nepristranost suca ima dva relativno jasno određena aspekta: subjektivni i objektivni. Riječ je o zahtjevima da sudac mora biti nepristran i da se mora vidjeti da je nepristran. Navedeni zahtjevi podjednako vrijede za sve postupke. ${ }^{48}$

47 Naime, Europski sud je u predmetu Campbell i Fell protiv Ujedinjenog Kraljevstva (1984.), § 78. naveo: „U određivanju može li se tijelo smatrati ‘neovisnim' - osobito o izvršnoj vlasti (executive) i o strankama u predmetu (vidi, inter alia, presudu Le Compte, Van Leuven i De Meyere od 23. lipnja 1981., § 55.) - Sud mora uzeti u obzir način imenovanja njegovih članova i trajanje mandata njihove službe (ibid., $\S 57$.), postojanje jamstava protiv izvanjskih pritisaka (vidi presudu Piersack od 1. listopada 1982., ...\$ 27.) i pitanje ostavlja li tijelo dojam neovisnosti (vidi Delcourt, presuda, 17. siječnja 1970., ... § 31.).“

${ }^{48}$ O tome jesu li pri odlučivanju o pravima i obvezama stranke u pojedinačnom slučaju ostvareni zahtjevi neovisnosti i nepristranosti u smislu članka 29, stavka 1. Ustava i članka 6, stavka 1. Konvencije v. rješenje Ustavnog suda broj: U-I-2393/2007 od 18. lipnja 2014. (www.usud.hr). Uobičajena formulacija 
Dakle, nepristranost suda/suca podrazumijeva da sud i njegov sastav jamče dovoljno sigurnosti, kojom isključuju svaku opravdanu sumnju u nepristranost suda. Navedeno stajalište Ustavni sud izrazio je u odluci broj: U-III-5423/2008 od 28. siječnja 2009., u kojoj je istaknuto da se (ne)pristranost suda provjerava primjenom subjektivnog i objektivnog testa. ${ }^{49}$ Međutim, prije nego što se pristupi provođenju testa sa subjektivnog i objektivnog aspekta, potrebno je utvrditi u kojoj fazi postupka je podnositelj imao saznanje o postojanju elemenata koji ukazuju na eventualno postojanje nepristranosti nekog suca te je li taj prigovor isticao tijekom postupka. $^{50}$

Iz svega navedenoga proizlazi da ocjena o tome je li u konkretnom slučaju o pravima i obvezama stranke odnosno o optužbi za kažnjivo djelo protiv nje odlučivao neovisni i nepristrani sud uvijek ovisi o osobitim okolnostima konkretnog slučaja, a u obzir se mora uzeti cijeli provedeni postupak kao jedinstvena cjelina, a ne samo jedan njegov stadij.

\section{PRAVO NA PRISTUP SUDU}

Za razliku od „prava na sud“ koje je, kako je prethodno navedeno, izrijekom priznato u članku 29, stavku 1. Ustava, pravo na pristup sudu Ustavni sud izveo je iz tog članka, sukladno jurisprudenciji Europskog suda. Naime, strasbourški sud je svojim pravnim tumačenjem pravo na pristup sudu izveo iz članka 6. Konvencije radi osiguranja stvarne zaštite konvencijskog prava koje u toj odredbi nije izrijekom utvrđeno, ali je implicitno sadržano. ${ }^{51}$

Ustavni sud smatrao je da je pravo na pristup sudu osnovno pravo koje omogućuje korištenje ostalih jamstava propisanih člankom 29, stavkom 1. Ustava, jer kada ne bi bilo jamstva prava na pristup sudu, značajke koje sudski postupak opisuju kao pošten i brz uopće ne bi imale nikakvu vrijednost ako sudski postupak ne bi započeo. Kako čitav sustav procesnih prava iz članka 29. Ustava počiva na ideji djelotvorne zaštite, to je moguće samo u slučaju da ta zaštita bude i omogućena. Stoga jasno proizlazi da pravo na pravično suđenje, kao najvažnije procesno pravo, sadrži i pravo na pristup sudu kao važan aspekt ,prava na sud“.

Europskog suda o nepristranosti suda/suca sadržana je u predmetu Parlov-Tkalčić protiv Hrvatske (2009.), $\S \S 78-80$.

49 V. odluku Ustavnog suda broj: U-III-5423/2008 od 28. siječnja 2009. (Narodne novine broj 16/09. i www.usud.hr).

50 Načelna stajališta u odnosu na nepristranost suda/suca Ustavni sud naveo je u odluci broj: U-III-6360/2010 od 15. listopada 2014., točka 5.1. (Narodne novine broj 133/14. i www.usud.hr).

51 V. Golder protiv Ujedinjenog Kraljevstva (1975.). O pravu na pristup sudu kao impliciranom pravu v. Šarin, D.: „Pravo na pristup sudu u praksi Europskog suda za ljudska prava“, Pravni vjesnik, Pravni fakultet u Osijeku, Osijek, 2015., god. 31, br. 3-4, str. 275-281. 
Ipak, valja napomenuti da je Ustavni sud i prije prethodno spomenute promjene članka 29, stavka 1. Ustava štitio pravo na pristup sudu, ali kroz utvrđenje povrede drugih ustavnih prava. ${ }^{52}$

Ustavi sud, danas, u odlukama navodi da je pravo svakoga na pristup sudu dio temeljnog ljudskog prava na pravično suđenje zajamčenog člankom 29, stavkom 1. Ustava, a podrazumijeva pristupačnost postupka sa svim obilježjima sudskog oblika ispitivanja. I samo pravo na pristup sudu ima nekoliko aspekata. Mogućnost iniciranja sudskog postupka radi donošenja odluke o pravima i obvezama stranke, iako sama po sebi nije dovoljna da bi se osiguralo pravo pristupa sudu, onaj je aspekt prava na pristup sudu bez kojeg ostala jamstva, sadržana u pravu pravičnog suđenja, ne bi mogla imati pravno značenje. ${ }^{53}$

\section{OGRANIČENJE PRAVA NA PRISTUP SUDU}

Pravo na pristup sudu nije apsolutno. Ono može biti zakonom ograničeno (članak 16. Ustava),${ }^{54}$ primjerice zakonom određenim pretpostavkama koje moraju biti ispunjene za podnošenje tužbe ili rokovima za ulaganje pravnih lijekova. Međutim, različita ograničenja mogu svesti pravo na pristup sudu na razinu koja bi dovela do toga da je sama bit ostvarenja tog prava ugrožena. Stoga, svako ograničenje mora biti ustanovljeno zakonom, mora imati legitimni cilj te mora postojati razumna razmjernost između ograničenja i cilja koji se tim ograničenjem želi postići.

Dosljedno tome, Ustavni sud, sukladno i praksi Europskog suda, smatra da je nesporno da pravo na pristup sudu nije i ne može biti apsolutno, već je podvrgnuto ograničenjima, budući da po samoj svojoj naravi zahtijeva regulaciju države, koja u tom pitanju ima izvjesnu slobodu procjene (margin of appreciation)..$^{55} \mathrm{Ta}$

52 Primjerice, Ustavni sud je u odluci broj: U-III-336/1993 od 1. lipnja 1994. (Narodne novine broj 50/94.) naveo: „Kako je Upravni sud Republike Hrvatske odlučio o tužbi kao nedopuštenoj, uskratio je tužitelju pravo na pristup sudu i time povrijedio ustavno pravo tužitelja na pravnu zaštitu protiv pojedinačnog akta, zajamčenu mu člankom 18. Ustava Republike Hrvatske“. I u odluci broj: U-III-504/1996 od 8. srpnja 1999. (Narodne novine broj 80/99. i www.usud.hr) Ustavni sud smatrao je da je došlo do povrede ustavnih načela i prava na koja se ustavnom tužbom ukazuje (članci 3., 26. i 115. stavak 3. Ustava), jer se ukazala ,neprihvatljivom apriorna uskrata prava na pristup sudu, prava na pravično suđenje i mogućnost ostvarenja stečenih prava građaninu - vlastitom državljaninu pred sudom vlastite države, koja mu prema kriteriju prebivališta odnosno prema teritorijalnom principu, a i drugim kriterijima, pripadaju“.

${ }_{53}$ Navedeno određenje prava na pristup sudu Ustavni sud dao je još u rješenju broj: U-I-949/1995 i dr. od 23. studenoga 2005. (www.usud.hr).

54 Naime, člankom 16. Ustava određeno je da se slobode i prava mogu ograničiti samo zakonom da bi se zaštitila sloboda i prava drugih ljudi te pravni poredak, javni moral i zdravlje. Međutim, svako ograničenje slobode ili prava mora biti razmjerno naravi potrebe za ograničenjem u svakom pojedinom slučaju.

55 V. Handyside protiv Ujedinjenog Kraljevstva (1976.), § 48; Poitrimol protiv Francuske (1993.), §§ 35-38; Levages Prestations Services protiv Francuske (1996.), § 40; Khalfaoui protiv Francuske (1999.), 
Dr. sc. Duška Šarin: Aspekti prava na pravično suđenje - pravo na pristup sudu kroz jurisprudenciju... Zbornik radova Pravnog fakulteta u Splitu, god. 53, 3/2016., str. 729.-762.

ograničenja, međutim, ne smiju umanjiti pristup sudu na takav način ili do takve mjere da time bude narušena sama bit „,prava na sud“. ${ }^{56}$ Takva se ograničenja također neće smatrati suglasnima članku 29, stavku 1. Ustava ako nisu propisana radi ostvarenja legitimnog cilja ili ne postoji razuman odnos razmjernosti između sredstava koja su upotrijebljena i cilja koji se namjeravao postići. ${ }^{57}$

Važno je napomenuti da je Ustavni sud u svojoj praksi prihvatio i stajalište Europskog suda ${ }^{58}$ prema kojem prava koja se štite Konvencijom moraju biti stvarna i djelotvorna (practical and effective), a ne teorijska ili prividna (theoretical or illusory), osobito u pogledu prava na pristup sudu u smislu važnog mjesta koje pravo na pravično suđenje ima u demokratskom društvu. ${ }^{59}$

\section{POSTUPOVNE PRETPOSTAVKE ZA PRISTUP SUDU}

Budući da je jurisprudencija Ustavnog suda pod velikim utjecajem prakse Europskog suda, Ustavni sud smatra da pravo na pristup sudu može biti podvrgnuto ograničenjima osobito kad je riječ o zakonskim pretpostavkama koje se tiču dopuštenosti ulaganja pravnih sredstava. Međutim, zadaća Ustavnog suda, kako je već rečeno, nije preuzeti ulogu sudova, koji su prvi pozvani interpretirati zakone. To se osobito tiče interpretacije zakonskih pravila postupovne naravi, kao što su pretpostavke za podnošenje pravnih sredstava. Zadaća Ustavnog suda ograničena je na ispitivanje jesu li učinci takve interpretacije sudova suglasni s Ustavom s aspekta zaštite ljudskih prava i temeljnih sloboda. ${ }^{60}$

$\S \S$ 42-54; Garcia Manibardo protiv Španjolske (2000.), §§ 44-45; Kreuz protiv Poljske (2001.), § 54; Yagtzilar i drugi protiv Grčke, (2001.), § 23; Truhli protiv Hrvatske (2001.), § 25. O načelu slobodnog polja procjene v. van Dijk, P., van Hoof, G. J. H.: "The margin of appreciation", Theory and Practice of the European Convention on Human Rights, Haag, Kluwer Law International, 1998., str. 82-97.

56 V. recentnije odluke Ustavnog suda broj: U-III-7011/2014 od 17. srpnja 2015. (www.usud.hr); broj: U-III-2268/2015 od 17. rujna 2015. (www.usud.hr).

57 Usp. Fayed protiv Ujedinjenog Kraljevstva (1994.), § 65; Bellet protiv Francuske (1995.), § 31; Levages Prestations Services protiv Francuske (1996.), § 40; Sotiris i Nikos Koutras ATTEE protiv Grčke (2000.), § 15; Belě̌ protiv Čě̌ke (2002.), § 61.

58 Tako je Europski sud u predmetu Kreuz protiv Poljske (2001.) posebno napomenuo: ,55. ... Sud naglašava da ograničenje postavljeno u odnosu na pristup sudu ili tribunalu neće biti sukladno članku 6 . stavku 1. osim ako teži legitimnom cilju, a postoji razumna veza razmjernosti između uloženih sredstava $i$ legitimnog cilja koji se želi ostvariti. (...) 57. I dalje s tim u vezi, Sud konačno želi ponoviti da je njegovo ispitivanje temeljeno na načelu da je namjera Konvencije zajamčiti ne prava koja su teorijska ili prividna (theoretical or illusory), već prava koja su stvarna i djelotvorna (practical and effective). To je naročito tako u pogledu prava na pristup sudovima u smislu važnog mjesta koje pravo na pošteno suđenje ima u demokratskom društvu (...).“ Usp. Airey protiv Irske (1979.), § 24; Garcia Manibardo protiv Španjolske (2000.), § 43 .

59 V., primjerice, odluke Ustavnog suda broj: U-III-1414/2012 od 19. prosinca 2012. (Narodne novine broj 10/13. i www.usud.hr); broj: U-III-1113/2015 od 20. svibnja 2015. (www.usud.hr).

60 I Europski sud je u brojnim odlukama naveo da zadaću tumačenja i primjene domaćeg prava prvenstveno imaju nacionalne vlasti i to sudovi. To se osobito odnosi na tumačenje postupovnih pravila 
Dr. sc. Duška Šarin: Aspekti prava na pravično suđenje - pravo na pristup sudu kroz jurisprudenciju... Zbornik radova Pravnog fakulteta u Splitu, god. 53, 3/2016., str. 729.-762.

Prema praksi Ustavnog suda sama činjenica da je podnositelj imao pravnu mogućnost podnošenja pravnih sredstava sudu ne dovodi nužno, sama po sebi, do ispunjenja pretpostavki koje proizlaze iz članka 29, stavka 1. Ustava. I dalje ostaje da se utvrdi je li stupanj tog pristupa dostatan da stranci osigura „pravo na sud“ sa stajališta načela vladavine prava u demokratskom društvu. ${ }^{61}$

\subsection{Pravo podnošenja određene vrste zahtjeva sudu}

Iako pravo na pristup sudu inherentno ,pravu na sud“ osigurava svima pravo da svaki zahtjev koji se odnosi na njihova prava i obveze podnesu sudu i da sud o tom zahtjevu odluči, zbog navedene podložnosti normiranju po nadležnim državnim tijelima, to pravo podložno je i određenim ograničenjima koja mogu biti povezana, primjerice, s uvjetima podnošenja određene vrste zahtjeva sudu.

Navedeno znači da je jamstvo ustavnog i konvencijskog ,prava na sud“ odnosno prava na pristup sudu oživotvoreno na prihvatljiv način kada je postupovnim pravilima unutarnjeg prava pojedine države osigurano pravo na podnošenje određenog zahtjeva sudu, ali je ono uređeno na način da je ograničeno, primjerice, vremenskim rokom, ${ }^{62}$ pravnim interesom podnositelja, krugom dopuštenih razloga,

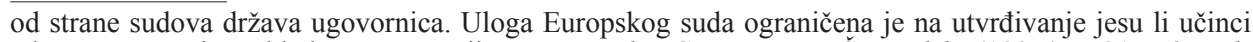
takvog tumačenja u skladu s Konvencijom. V. Tejedor Garcia protiv Španjolske (1997.), § 31; Pérez de Rada Cavanilles protiv Španjolske (1998.), § 43; Miragall Escolano i drugi protiv Španjolske (2000.), §§ 33-39.

${ }^{61}$ V. odluke Ustavnog suda broj: U-III-4188/2008 od 12. lipnja 2012. (www.usud.hr); broj: U-III-6002/2011 od 11. listopada 2012. (Narodne novine broj 121/12. i www.usud.hr); te recentniju odluku broj: U-III-296/2014 od 17. srpnja 2015. (www.usud.hr). Istovjetno stajalište u odnosu na članak 6, stavak 1. Konvencije zastupa Europski sud koji je još u predmetu Ashingdane protiv Ujedinjenog Kraljevstva (1985.), § 57, istaknuo da ,stupanj pristupa sudu mora biti dovoljan da pojedincu osigura 'pravo na sud', poštujući vladavinu prava u demokratskom društvu“ te da „primijenjena ograničenja ne smiju ograničiti ili smanjiti pristup pojedincu na takav način ili u tolikoj mjeri da bude narušena sama bit toga prava“. Europski sud opetovano ističe da su pravila koja uređuju formalne „korake“ koji se moraju poduzeti pri podnošenju pravnog sredstva usmjerena na osiguranje „pravilnog upravljanja pravdom“ (proper administration of justice), osobito pravne sigurnosti (legal certainty). Stranke uvijek imaju pravo očekivati da će se na njihov slučaj primijeniti postojeća pravila. S druge strane, sama ta pravila ne smiju biti takva da sprečavaju osobe da se posluže raspoloživim pravnim sredstvom. Usp. Sotiris i Nikos Koutras ATTEE protiv Grčke (2000.), § 20; Beleš protiv Češke (2002.), §\$ 49. i 60.

62 Međutim, u odluci broj: U-III-2342/2006 od 11. srpnja 2007. (Narodne novine broj 86/07. i www. usud.hr) Ustavni sud utvrdio je povredu ustavnog prava podnositelja na sud jer tužba podnositelja nije ispitana pred sudom, ocijenivši da nejasnoće vezane uz podnositeljevo pravo na podnošenje tužbe radi proglašenja ovrhe nedopuštenom i nakon proteka roka koji mu je odredio ovršni sud, sve do dovršetka ovršnog postupka, Vrhovni sud Republike Hrvatske (u daljnjem tekstu: Vrhovni sud) u osporenom rješenju nije razmatrao, te da je osporeno rješenje Vrhovnog suda „koje je dovelo do toga, da tužba podnositelja radi proglašenja ovrhe nedopuštenom uopće nije ispitana pred sudom, dovelo do prekomjernog ograničavanja ustavnog prava podnositelja na sud u smislu članka 29. stavka 1. Ustava i članka 6. stavka 1. Konvencije". Značaj ove odluke Ustavnog suda je u tome što njezini dosezi prelaze okvire konkretnog slučaja. Naime, Vrhovni sud prihvatio je stajalište Ustavnog suda u svezi s neprekluzivnosti navedenog roka, te je utvrdio da je u takvoj situaciji riječ o instruktivnom roku, a prekoračenje sudskog instruktivnog roka za poduzimanje određene sudske radnje nema za posljedicu odbacivanje podneska, odnosno tužbe. 
Dr. sc. Duška Šarin: Aspekti prava na pravično suđenje - pravo na pristup sudu kroz jurisprudenciju... Zbornik radova Pravnog fakulteta u Splitu, god. 53, 3/2016., str. 729.-762.

krugom dokaznih sredstava - koja se mogu odnositi na dopuštenost ili na osnovanost zahtjeva, nadležnošću suda prema određenim kriterijima i sl. ${ }^{63}$

Nasuprot tome, u odluci broj: U-III-1801/2006 od 20. svibnja 2009. Ustavni sud utvrdio je povredu podnositeljičinog ustavnog prava na pristup sudu jer se nije proveo sudski postupak po zahtjevu podnositeljice za hitnim povratkom nezakonito oduzetog djeteta. ${ }^{64}$ Naime, Ustavni sud utvrdio je da je, sukladno članku 5. Zakona o sudovima ${ }^{65}$ za provedbu postupaka po Haškoj konvenciji o građanskopravnim aspektima međunarodne otmice djece ${ }^{66}$ nadležan redovni sud koji o zahtjevu odlučuje u izvanparničnom postupku. Odredbe Haške konvencije o građanskopravnim aspektima međunarodne otmice djece koje predviđaju osnivanje središnjeg državnog tijela, koje će izvršavati obveze koje konvencija predviđa za to tijelo, naime, ne utječu na nadležnost sudova, jer je to tijelo predviđeno samo u svrhu pomoći osobama čijoj je zaštiti ta konvencija namijenjena. ${ }^{67}$

Navedeni primjer, dakle, pokazuje da međunarodni ugovor nije strukturalno ograničenje koje bi moglo dovesti u pitanje pravo na pristup domaćem sudu.

63 Usp. odluke Ustavnog suda u kojima je utvrđena povreda zbog prekomjernog ograničavanja prava na pristup sudu, broj: U-III-539/2008 od 12. lipnja 2012. (Narodne novine broj 75/12. i www. usud. hr); broj: U-III-3189/2009 od 14. siječnja 2010. (Narodne novine broj 13/10. i www.usud.hr) u kojoj je Ustavni sud utvrdio da podnositelja ograničavanje prava na pristup sudu „,tavlja u položaj suprotan samoj biti njegova prava - u položaj u kojem je onemogućeno odlučivanje o njegovom zahtjevu“. Navedeno stajalište Ustavni sud potvrdio je i u odluci broj: U-III-2584/2008 od 1. travnja 2010. (Narodne novine broj 126/10. i www.usud.hr).

${ }^{64}$ U konkretnom slučaju, ustavna tužba podnesena je protiv rješenja Županijskog suda u Vukovaru, kojim je odbijena žalba podnositeljice izjavljena protiv rješenja Općinskog suda u Vukovaru. Tim je rješenjem odbačen podnositeljičin zahtjev za hitnim povratkom nezakonito odvedenog djeteta kao nedopušten. Prvostupanjski sud je u obrazloženju osporenog rješenja naveo da je zahtjev za hitnim povratkom nezakonito oduzetog djeteta odbacio kao nedopušten zbog toga što je stranka zahtjev za povratak djeteta podnijela neposredno sudu, za što po shvaćanju tog suda nije bila ovlaštena. Po mišljenju tog suda, podnositeljica je trebala zahtjev najprije dostaviti nadležnom ministarstvu koje bi zahtjev podnositeljice i popratnu dokumentaciju prvo dostavilo nadležnom Centru za socijalnu skrb i preispitalo mogućnosti dobrovoljnog povratka djeteta.

${ }_{65}$ V. članak 5. Zakona o sudovima (Narodne novine broj 150/05., 16/07. i 113/08.).

${ }^{66}$ Haška konvencija o građanskopravnim aspektima međunarodne otmice djece (Narodne novine Međunarodni ugovori, broj 4/94.).

67 Zato je Ustavni sud zaključio: „8. (...) Stoga je pogrešno tumačenje Županijskog i Općinskog suda u Vukovaru da se podnositeljica nije mogla neposredno obratiti sudu sa zahtjevom za povratak nezakonito odvedenog djeteta. Ako su bili ispunjeni i svi drugi uvjeti za zasnivanje sudske nadležnosti u ovom slučaju, sudski se postupak morao provesti. Otklanjanjem nadležnosti za postupanje navedeni sudovi su povrijedili podnositeljičino ustavno pravo na pristup sudu koje jamči članak 29. stavak 1. Ustava (...)“. V. odluku Ustavnog suda broj: U-III-1801/2006 od 20. svibnja 2009. (Narodne novine broj 67/09. i www. usud.hr). 


\subsection{Pravo na pristup sudu kroz djelotvoran pravni lijek}

Pravo na pristup sudu podvrgnuto je ograničenjima i kad je riječ o uvjetima koji se tiču dopustivosti ulaganja pravnih lijekova, ukoliko takva ograničenja ispunjavaju prethodno navedene kriterije. To znači da je jamstvo ustavnog i konvencijskog „prava na sud“, odnosno impliciranog prava na pristup sudu realizirano na prihvatljiv način kada je, primjerice, postupovnim pravilima unutarnjeg prava pojedine države osigurano pravo na podnošenje pravnog lijeka protiv odluke određenog tijela, ali je uređeno na način da je ograničeno vremenskim rokom, pravnim interesom podnositelja pravnog lijeka, krugom dopuštenih razloga za podnošenje pravnog lijeka, zabranom podnošenja pravnog lijeka protiv odluke kojom je o njemu odlučeno, vrijednošću predmeta spora i sl. ${ }^{68}$

Zakonodavac, dakle, opravdano može postupovnim odredbama ograničiti pravo na pravni lijek u interesu učinkovitog pravosuđa, ali propust valjane primjene takvih odredbi značit će uvijek povredu prava na pristup pravnom lijeku kada predstavlja proizvoljno tumačenje mjerodavnog (postupovnog) prava ${ }^{69}$ ili kada podnositelju pravnog lijeka nameće nerazmjerno ograničenje njegovog prava. ${ }^{70} \mathrm{O}$ potonjem će biti riječ, primjerice, u slučaju kada sud koji odlučuje u povodu pravnog lijeka odredbe o dopuštenosti primjenjuje ,na previše formalistički način“ “.

Navedeno znači da će Ustavni sud u svakom konkretnom slučaju ispitati o kakvim se ograničenjima radilo i jesu li ona umanjila pristup određenom pravnom lijeku na takav način ili u tolikoj mjeri da je bila umanjena ili oslabljena sama bit toga prava. ${ }^{72}$

\subsubsection{Jamstvo prava na žalbu}

Pitanje osiguranja djelotvornog pravnog lijeka jedno je od temeljnih procesnih jamstava u svim pravnim postupcima, a pravo na žalbu je zbog svog iznimnog značaja zajamčeno Ustavom kao temeljno ljudsko pravo. Naime, člankom 18.

68 O takvom pristupu Ustavnog suda v., primjerice, odluku broj: U-III-4401/2005 od 30. travnja 2008. (www.usud.hr).

69 Istovjetno stajalište zastupa i Europski sud. Usp. Prince Hans Adam II of Liechtenstein protiv Njemačke (2001.), § 69.

70 Usp. Zwiazek Nauczycielstwa Polskiego protiv Poljske (2004.), § 38; Mortier protiv Francuske (2001.), § 36-39.

71 Usp. Stone Court Shipping Company, C.o. protiv Španjolske (2003.), § 36-43; Bulena protiv Češke (2004.), § 35; Kadlec i drugi protiv Češke (2004.), § 26-30; Boulougouras protiv Grčke (2004.), § 26-27.

72 Tako i Europski sud smatra da iako članak 6. Konvencije ne obvezuje države ugovornice da osnuju žalbene ili kasacijske sudove, kad takvi sudovi postoje oni moraju poštovati jamstva sadržana u članku 6 ., primjerice, da se strankama u postupku jamči djelotvorno pravo na pristup sudovima. V. Brualla Gómez de la Torre protiv Španjolske (1997.), § 37; Kozlica protiv Hrvatske (2006.), § 32. i Angel Angelov protiv Bugarske (2007.), § 31 . 
Ustava zajamčeno je pravo na žalbu protiv pojedinačnih pravnih akata donesenih u postupku prvog stupnja pred sudom ili drugim ovlaštenim tijelom. Pravo na žalbu može biti samo iznimno isključeno i to jedino u slučajevima određenima zakonom i ako je u tim slučajevima osigurana druga pravna zaštita. To znači da će u svim ostalim slučajevima doći do povrede ustavnog prava na žalbu, a time posljedično i do povrede prava na pristup sudu.

Dobra ilustracija navedenoga jest odluka Ustavnog suda broj: U-III-3920/2003 od 11. siječnja 2006. kojom je Ustavni sud utvrdio povredu podnositeljevog ustavnog prava na žalbu propisanog člankom 18, stavkom 1. Ustava, te zbog toga i onemogućavanje podnositelju pristupa sudu. ${ }^{73}$ Ustavni sud je, naime, zaključio da je došlo do pogrešne primjene zakona:

„4. (...) Budući da se tužena o žalbi umješača (podnositelja) nije očitovala u smislu da je izjavljivanjem tog pravnog lijeka umješač (podnositelj) postupio suprotno njezinim pravnim radnjama (interesima), Ustavni sud ocjenjuje da je Županijski sud u Zagrebu, odbacivanjem žalbe podnositelja kao nedopuštene, u dijelu osporenog rješenja pogrešno protumačio i primijenio odredbu članka 208. stavka 4. Zakona o parničnom postupku.

5. Polazeći od utvrđenja iz točke 4. obrazloženja ove odluke, Ustavni sud ocjenjuje da je Županijski sud u Zagrebu, prilikom zauzimanja stajališta o dopustivosti žalbe podnositelja kao umješača, povrijedio podnositelju ustavno pravo na žalbu propisano odredbom članka 18. stavka 1., čime je onemogućio podnositelju i pristup sudu zajamčen odredbom članka 29. stavka 1. Ustava." ${ }^{77}$

Međutim, nemogućnost podnošenja žalbe može dovesti i do povrede same biti prava na pristup sudu. Naime, Ustavni sud utvrdio je povredu prava na pristup sudu u slučaju u kojem stranci, u konkretnom slučaju podnositeljima okrivljenima u kaznenom postupku, nije bilo omogućeno podnijeti pravni lijek po odabranom branitelju, utvrdivši da u odnosu na pravo ulaganja žalbe po odabranom branitelju mjerodavno kazneno pravo ne predviđa ograničavanje pristupa sudu okrivljenika. Stoga je Ustavni sud odlukom broj: U-III-3332/2013 od 7. svibnja 2013. usvojio ustavnu tužbu podnositelja jer im je uskraćen pristup sudu, na način da prvostupanjski sud nije dostavio nepravomoćnu odluku odabranom branitelju:

73 U konkretnom slučaju, rješenjem Općinskog suda u Zagrebu, podnositelju je dopušteno miješanje u parnični postupak na strani tužene. Podnositelj je bio prisutan na svim glavnim raspravama u postupku, poduzimao je sve zakonom dopuštene radnje kao stranka u postupku, pa je tako i protiv prvostupanjske presude u zakonskom roku uložio žalbu, koju tužena nije osporila. Ustavni sud je utvrdio da je u konkretnom slučaju mjerodavan članak 208, stavci 1., 3. i 4. Zakona o parničnom postupku (Narodne novine broj 53/91., 91/92., 112/99., 88/01. i 117/03.).

74 V. odluku Ustavnog suda broj: U-III-3920/2003 od 11. siječnja 2006. (Narodne novine broj 15/06. i www.usud.hr). 
„8. Ustavni sud, stoga, ocjenjuje da su podnositelji bili onemogućeni u ostvarenju svog ustavnog prava na pristup sudu, jer je u konkretnom slučaju došlo do povrede same biti podnositeljevih prava na sud, a time i do povrede prava na pravično suđenje zajamčenog člankom 29. stavkom 1. Ustava،“"75

\subsubsection{Pravo na reviziju (pristup revizijskom sudu)}

Člankom 62, stavkom 3. Ustavnog zakona o Ustavnom sudu Republike Hrvatske određeno je da je u stvarima u kojima je dopuštena revizija u parničnom ili izvanparničnom postupku pravni put iscrpljen nakon što je odlučeno i o tim pravnim sredstvima ${ }^{76}$ To konkretno znači da će Ustavni sud, u takvim slučajevima, ispitati u postupku u povodu ustavne tužbe i je li podnositelju bio omogućen pristup revizijskom sudu odnosno njegovo pravo na reviziju, te ukoliko utvrdi da je došlo do povrede podnositeljevog prava na pristup tom pravnom lijeku, usvojit će ustavnu tužbu i vratiti predmet na ponovni postupak revizijskom sudu. ${ }^{77}$

Ipak, pojedina su ograničenja prava na podnošenje revizije dopuštena. ${ }^{78}$ Stoga Ustavni sud u odlukama navodi da, polazeći od revizije kao izvanrednog pravnog lijeka, koji se podnosi protiv drugostupanjske sudske odluke kojom se postupak pravomoćno završava i o kojoj odlučuje Vrhovni sud ispitujući zakonitost odluka nižestupanjskih sudova, revizija je nužno po prirodi parničnog postupka pravni lijek za čije su podnošenje utvrđene strože pretpostavke, a razlozi zbog kojih se može podnijeti su ograničeni. ${ }^{79}$

Ustavni sud izrazio je svoje stajalište i o prihvatljivim ograničenjima prava na podnošenje izvanredne revizije. U tom smislu, Ustavni sud naglašava kako

75 V. odluku Ustavnog suda broj: U-III-3332/2013 od 7. studenoga 2013. (Narodne novine broj 138/13. i www.usud.hr).

76 V. članak 62, stavak 3. Ustavnog zakona o Ustavnom sudu Republike Hrvatske (Narodne novine broj 99/99., 29/02. i 42/02. - pročišćeni tekst).

77 I prema praksi Europskog suda postupci po reviziji ili kasacijskoj žalbi spadaju u djelokrug članka 6, stavka 1. Konvencije. V. Cobianchi protiv Italije (2000.), §§ 8. i 11.; H. E. protiv Austrije (2002.), §§ 14. $\mathrm{i} 18$.

$78 \mathrm{U}$ tom smislu Ustavni sud prihvaća ustaljeno pravno stajalište Europskog suda izraženo i u predmetu Bulfracht Ltd. protiv Hrvatske (2011.): ,35. ... Način na koji se članak 6. stavak 1. primjenjuje na žalbene ili kasacijske sudove ovisi o posebnim značajkama dotičnoga postupka, te treba uzeti u obzir ukupnost postupka vođenog u domaćem pravnom poretku i ulogu kasacijskog suda u njemu; uvjeti dopuštenosti revizije mogu biti stroži od onih za redovnu žalbu (vidi, inter alia, presudu u predmetu Brualla Gómez de la Torre protiv Španjolske, 19. prosinca 1997., Izvješća o presudama i odlukama 1997., VIII, str. 2956, § 37).“

79 Tako se redovna revizija može podnijeti samo zbog bitnih povreda odredaba parničnog postupka (uz određena značajna ograničenja u usporedbi s bitnim povredama zbog kojih se može izjaviti žalba) i zbog pogrešne primjene materijalnog prava, dok se izvanredna revizija može podnijeti i pobijana se presuda može ispitivati samo zbog materijalnopravnog ili postupovnopravnog pitanja zbog kojeg je „dopuštena“, dakle, zbog pitanja važnog za osiguranje jedinstvene primjene zakona i ravnopravnosti svih u njegovoj primjeni. V., primjerice, odluku Ustavnog suda broj: U-I-885/2013 od 11. srpnja 2014. (Narodne novine broj 89/14. i www.usud.hr). 
Dr. sc. Duška Šarin: Aspekti prava na pravično suđenje - pravo na pristup sudu kroz jurisprudenciju... Zbornik radova Pravnog fakulteta u Splitu, god. 53, 3/2016., str. 729.-762.

nije prihvatljivo da se izvanrednom revizijom stranke koriste pokušavajući pred najvišim sudom u zemlji dokazati da su nadležni sudovi u pojedinom konkretnom slučaju pogrešno protumačili ili primijenili pravo, ili povrijedili pravila postupka, ili učinili druge povrede zakona protiv kojih postoje i za koje su namijenjena druga pravna sredstva, ili jednostavno još jednom iskazali svoje nezadovoljstvo pravomoćnim ishodom sudskog postupka, sve pod plaštom brige za osiguranje jedinstvene primjene zakona i ravnopravnosti građana. Ponašanje stranaka u parničnim postupcima mora biti odgovorno, uz strogo poštovanje svrhe i smisla zakonom priznatih pravnih sredstava zaštite..$^{80}$

Dosljedno tome, upravo prethodno navedeni „previše formalistički način“ tumačenja postupovnog prava o dopuštenosti podnošenja pravnih lijekova pa tako i revizije najčešći je razlog usvajanja ustavnih tužbi podnositelja. Izvrsna ilustracija argumenata u tom smislu može se naći u predmetu broj: U-III-2646/2007. ${ }^{81}$ Ustavni sud je iz utvrđenog stanja zaključio:

„5.3. ... Čninjenica što je u međuvremenu novac obezvrijeđen ne mijenja koncepciju pravnih normi mjerodavnih za građanskopravne odnose u konkretnom slučaju: njihova regulatorna svrha ostaje ista i ti pravni odnosi ostaju nepromijenjeni u svojem karakteru i opsegu. Tvrditi u takvoj situaciji da je vrijednost spora o tim odnosima zbog promjene nominalnog iznosa njihovih novčanih obilježja umanjena znači formalistički prihvatiti privid kao istinu. To je pogrešni oblik pravnog tumačenja - kada se riječi ili brojke uzimaju doslovno, a da se ne pita ništa o njihovom značenju - jer ne predstavlja niti valjano gramatičko tumačenje, a pogotovo ne pravilnu primjenu teleološkog tumačenja koje zahtijeva da se otkrije svrha zakona i utvrde vrijednosti za kojima ide zakon.

5.4. Kada se, dakle, Vrhovni sud u svojoj ocjeni podnositeljičine revizije poslužio pogrešnim, formalističkim, tumačenjem postupovnog prava o mjerodavnom vrijednosnom kriteriju dopuštenosti te revizije, uzevši da vrijednost 1 suvlasničkog

80 V., primjerice, odluku Ustavnog suda broj: U-III-870/2015 od 7. listopada 2015. (www.usud.hr).

81 U konkretnom slučaju podnositeljica je, između ostalog, smatrala da je Vrhovni sud rješenjem kojim je zbog premale vrijednosti predmeta spora odbacio njezinu reviziju, učinio propust da, sukladno članku 29, stavku 1. Ustava, pravično odluči o njezinom pravu na podnošenje pravnog lijeka. Naime, Vrhovni sud je osporenim rješenjem odbacio reviziju podnositeljice pozivom na odredbu članka 382, stavaka 2. i 3. Zakona o parničnom postupku (Narodne novine broj 53/91., 91/92. i 112/99.) prema kojoj revizija nije dopuštena u imovinskopravnim sporovima u kojima se tužbeni zahtjev odnosi na tražbinu u novcu, predaju stvari ili izvršenje kakve druge činidbe ako vrijednost predmeta spora koju je tužitelj u tužbi naveo ne prelazi iznos od 100.000,00 kn. Kako je u provedenom parničnom postupku ustanovljeno da je vrijednost predmeta spora u času podnošenja revizije, a nakon stupanja na snagu članka 4 . i članka 10, stavka 3. Zakona o izmjenama i dopunama Zakona o parničnom postupku (Narodne novine broj 112/99.) iznosila svega 0,12 kuna, Vrhovni sud je zaključio da je u konkretnom slučaju revizija protiv takve pravomoćne presude nedopuštena. Taj je navod obrazložen monetarnim promjenama u Republici Hrvatskoj, posebice denominacije hrvatske valute, uslijed kojih bi se nominalna vrijednost $1 / 2$ suvlasničkog dijela zgrade u Zagrebu, u razdoblju između 1987. do 2007. godine iz 120.000,00 dinara promijenila u 0,12 kuna. 
Dr. sc. Duška Šarin: Aspekti prava na pravično suđenje - pravo na pristup sudu kroz jurisprudenciju... Zbornik radova Pravnog fakulteta u Splitu, god. 53, 3/2016., str. 729.-762.

dijela obiteljske kuće u Zagrebu iznosi 0,12 kuna (!) povrijedio je njezino pravo na pristup tom pravnom lijeku. ..." ${ }^{82}$

Ustavni sud u citiranoj je odluci izrazio i stajalište o potrebi teleološkog tumačenja pravnih normi koje zahtijeva da se otkrije svrha zakona i utvrde vrijednosti za kojima ide zakon, za razliku od formalističkog (doslovnog) tumačenja kakvim se poslužio Vrhovni sud.

Međutim, hoće li doći do povrede prava na pristup revizijskom sudu, uvijek će ovisiti o kakvim se ograničenjima radilo i jesu li ona umanjila pristup reviziji na takav način i u tolikoj mjeri da je podnositelju u osobitim okolnostima konkretnog slučaja bila umanjena ili oslabljena sama bit toga prava.

\subsection{Pravo na pristup sudu u određenim sudskim postupcima}

Iako pravo na pristup sudu može biti podložno propisanim ograničenjima, načelno se ne radi o povredi prava na pristup sudu ako bi ograničenje tog prava proizlazilo, primjerice, iz zakonskog razgraničenja sudbene i upravne nadležnosti. Naravno, samo pod uvjetom osiguranja pravnog puta koji otvara moguénost da i stvari iz upravne nadležnosti budu podvrgnute sudskoj kontroli.

Slijedom toga, sama po sebi nije prijeporna činjenica da je u nekom sudskom postupku sud otklonio svoju nadležnost za odlučivanje o određenom pitanju i stranku u postupku uputio da to pitanje rješava pred upravnim tijelom. Prijeporno može biti koliko je takvo ograničenje, prije svega, utemeljeno na mjerodavnom pravu, a zatim i koliko je u takvom slučaju stvarna i djelotvorna zaštita prava pod uvjetima kojima je pravo na pristup sudu ograničeno.

Skrenimo pažnju na to da je stav da se jamstva prava na pravično suđenje primjenjuju i na sudski postupak pred upravnim sudom (upravni spor), uređen

82 V. odluku Ustavnog suda broj: U-III-2646/2007 od 18. lipnja 2008. (Narodne novine broj 104/08.). Sličan slučaj iz prakse Ustavnog suda zabilježen je u odluci broj: U-III-4361/2008 od 10. lipnja 2009. (Narodne novine broj 87/09. i www.usud.hr) u kojoj je Ustavni sud zbog istih razloga utvrdio povredu podnositeljevog prava na pristup reviziji. Do povrede prava na pristup (revizijskom) sudu može dovesti i nejednak procesni položaj stranke u postupku, a što je utvrđeno u odluci Ustavnog suda broj: U-III-745/2009 od 1. travnja 2010. (Narodne novine broj 50/10. i www.usud.hr) upravo zbog „formalističkog pristupa“ Vrhovnog suda pravu na izjašnjavanje o vrijednosti predmeta spora. Slična situacija notirana je i u odluci broj: U-III-727/2010 od 11. studenoga 2010. (www.usud.hr) u kojoj je Ustavni sud zaključio da je ,neposredna posljedica nejednakog procesnog položaja podnositelja u odnosu na tuženika-protutužitelja, a u svezi s pitanjem prava na izjašnjavanje o vrijednosti predmeta spora, dovela ... do povrede prava podnositelja na pristup revizijskom sudu, jer je Vrhovni sud zanemario činjenicu da je tuženik-protutužitelj vrijednost predmeta spora naznačio iznosom koji je omogućio podnositelju izjavljivanje revizije“. Usp. odluke Ustavnog suda broj: U-III-4863/2013 od 8. travnja 2014. (www.usud. hr) i broj: U-III-790/2014 od 18. studenoga 2015. (www.usud.hr) u kojima su ustavne tužbe odbijene (Vrhovni sud odbacio je reviziju zbog nedostatne vrijednosti predmeta spora u parničnom postupku), jer je Ustavni sud ocijenio, ,da podnositelj nije bio nerazmjerno onemogućen u svom ustavnom pravu na pristup sudu". 
člankom 19, stavkom 2. Ustava, ${ }^{83}$ Ustavni sud prvi put iznio tek 2010. godine ${ }^{84}$ Naime, Ustavni sud naveo je da pravila i sredstva dokazivanja čine dio cjeline postupovnih pravila upravnog postupka, sadržanih u Zakonu o općem upravnom postupku $^{85}$ i kao takva neodvojiva su sastavnica postupovnih jamstava pravičnog suđenja, zaštićenih Ustavom. Stoga, Ustavni sud štiti ustavno jamstvo pravičnog suđenja (odlučivanja) ispitujući eventualno postojanje postupovnih povreda u postupcima pred sudovima i drugim državnim tijelima, odnosno tijelima koja imaju javne ovlasti. ${ }^{86}$

Ustavni sud, nadalje, stajališta je da je upravni spor pred upravnim sudom uvijek spor između fizičke odnosno pravne osobe o čijim je pravima i obvezama odlučilo državno tijelo, i, s druge strane, autoriteta državne vlasti izraženog kroz upravni akt koji se tužbom pobija. Takvom odnosu strana u sporu imanentan je određeni stupanj rizika od pojave nejednakosti u procesnom položaju tužitelja te od zapostavljanja značaja principa neovisnosti i nepristranosti u suđenju, o kojem pravu je prethodno bilo riječi. Pored navedenoga, tužba upravnom sudu jest jedino sredstvo sudske zaštite koje stoji na raspolaganju građaninu protiv odluke tijela državne uprave. Stoga, ignoriranje argumentacije na kojoj tužitelj u upravnom sporu temelji svoju tužbu odnosno izostanak očitovanja o njegovim bitnim navodima može imati za posljedicu de facto onemogućavanje pristupa sudu sprečavanjem stranke da se sa svojim zahtjevom, izuzev na formalnoj razini, obrati sudu i da sud nastali spor razriješi. ${ }^{87}$

S obzirom na načelna pravna stajališta na koja se Ustavni sud pozvao u odluci broj: U-III-1/2009 od 3. studenoga 2010., uzimajući u obzir posebnu prirodu zadaća (tadašnjeg) Upravnog suda Republike Hrvatske (u daljnjem tekstu: Upravni sud) i s tim u vezi stajalište Europskog suda, smatramo da je ta odluka od iznimne važnosti za cjelokupni hrvatski pravni sustav, a da njezini dosezi prelaze granice i značenje konkretnog predmeta u kojem je donesena. Stoga je prikazana u nastavku teksta.

83 Naime, stavkom 2. članka 19. Ustava zajamčeno je ustavno pravo na sudsku kontrolu zakonitosti upravnih akata, koja podrazumijeva stvarnu i učinkovitu, neovisnu i nepristranu sudsku zaštitu od nezakonitih akata tijela državne uprave i drugih tijela s javnim ovlastima.

84 V. odluku Ustavnog suda broj: U-III-1001/2007 od 7. srpnja 2010. (Narodne novine broj 99/10. i www.usud.hr).

85 Zakon o općem upravnom postupku (Narodne novine broj 47/09.).

86 Pružajući tu zaštitu, Ustavni sud sagledava cjelokupan postupak kao jedinstvenu cjelinu te ocjenjuje je li on bio vođen na način koji podnositelju osigurava pravično suđenje (odlučivanje), odnosno je li tijekom postupka počinjena povreda takvog značenja da postupak kao cjelinu čini nepravičnim za podnositelja.

87 V. odluku Ustavnog suda broj: U-III-6002/2011 od 11. listopada 2012. (Narodne novine broj 121/12. i www.usud.hr) u kojoj je Ustavni sud izrazio shvaćanja o prirodi upravnog spora. O tome v. i u recentnijoj odluci broj: U-III-296/2014 od 17. srpnja 2015. (www.usud.hr). Usp. i odluke Ustavnog suda broj: 4809/2010 od 20. ožujka 2014. (www.usud.hr); broj: U-III-815/2013 od 8. svibnja 2014. (www. usud.hr). O dopuštenosti izjavljivanja žalbe u upravnom sporu v. Galić, A., Đerđa, D.: „Žalba u upravnom sporu“, Odvjetnik, Zagreb, 2014., br. 5-6., str. 12-30. 
Zbog povrede same biti podnositeljeva prava na sud Ustavni sud tom odlukom ukinuo je osporeno rješenje Upravnog suda i vratio predmet Upravnom sudu na ponovni postupak. ${ }^{88}$ Ustavni sud utvrdio je da je podnositelj u konkretnom slučaju imao pristup Upravnom sudu, ali samo do stupnja utvrđenja da je njegova tužba nedopuštena zbog toga što nema punomoćnika u Republici Hrvatskoj, a nije ga imenovao ni prigodom podnošenja tužbe.

Načelno pravno stajalište Ustavnog suda bilo je da je za a limine odbacivanje tužbe u upravnom sporu, bez obveze nadležnog suda da prethodno pozove tužitelja da u ostavljenom roku poduzme propuštenu procesnu radnju i pri tome ga pouči što i kako treba učiniti te ga upozori na posljedice koje cee nastati ako ne postupi po traženju suda, potrebno jasno, precizno i svima dostupno zakonsko postupovno pravilo s predvidljivim posljedicama za one na koje se primjenjuje.

S tog je aspekta Ustavni sud primijetio da način na koji se primjenjuje članak 29, stavak 1. Ustava ovisi i o posebnim obilježjima sudskog postupka o kojemu je riječ. Naime, osim što se cjelokupni postupak u kojem se odlučuje o nečijem pravu ili obvezi mora sagledavati kao jedinstvena cjelina, važno mjesto u ispitivanju prihvatljivosti nametnutih ograničenja ustavnom pravu na pristup sudu zauzima i uloga pojedinog suda u domaćem pravnom poretku, odnosno posebna obilježja postupka o kojem je riječ, zbog čega je potrebno uvijek uzimati u obzir i ulogu koju viši sudovi imaju u tom postupku.

Polazeći od tih načelnih pravnih stajališta, a uzimajući u obzir posebnu prirodu zadaća Upravnog suda u kontroli upravnih akata, i u to vrijeme, jedinstveni jednostupanjski ustroj upravnog sudstva u Republici Hrvatskoj, ${ }^{89}$ Ustavni sud smatrao je prihvatljivim na konkretan slučaj primijeniti stajalište Europskog suda u predmetu Sotiris i Nikos Koutras ATTEE protiv Grčke (2000.), kako uzimajući u obzir posebnu prirodu (sudske) kontrole upravnih akata koju vrši (grčki) Visoki upravni sud, nije prihvatljivo da postupak pred tim sudom bude pretjerano

88 Činjenice u konkretnom predmetu bile su sljedeće: podnositelj, državljanin Bosne i Hercegovine, podnio je ustavnu tužbu protiv rješenja Upravnog suda, kojim mu je odbačena tužba kao nedopuštena, jer se podnositelj, u svojstvu tužitelja u upravnom sporu, nalazio u inozemstvu, a nije imao punomoćnika u Republici Hrvatskoj niti ga je prigodom podnošenja tužbe imenovao. Tužbu u upravnom sporu podnositelj je podnio zbog nedonošenja rješenja o njegovom zahtjevu za odobrenje stalnog boravka u Republici Hrvatskoj u zakonom propisanim rokovima.

89 Naime, Zakonom o izmjenama i dopunama Zakona o sudovima (Narodne novine broj 153/09.) promijenjen je ustroj upravnog sudstva u Republici Hrvatskoj na način da su specijalizirani sudovi postali $i$ upravni sudovi (ustanovljeni za područje jedne ili više županija) te Visoki upravni sud Republike Hrvatske (ustanovljen za područje Republike Hrvatske) koji, između ostalog, odlučuje o žalbama protiv presuda upravnih sudova i rješenja protiv kojih je dopuštena žalba (v. članke 1-6). O samom putu reformi upravnog sudovanja u Republici Hrvatskoj i kriterijima kojima su bile vođene v. Koprić, I.: „Europski standardi i modernizacija upravnog sudovanja u Hrvatskoj“, Europeizacija upravnog sudovanja u Hrvatskoj, Institut za javnu upravnu, Zagreb, 2014., str. 12-34. 
Dr. sc. Duška Šarin: Aspekti prava na pravično suđenje - pravo na pristup sudu kroz jurisprudenciju... Zbornik radova Pravnog fakulteta u Splitu, god. 53, 3/2016., str. 729.-762.

formalistički jer predstavlja sud prvog i posljednjeg stupnja, budući da ni prije ni poslije njega podnositeljev predmet ne može razmatrati sud. ${ }^{90}$

Sukladno tome, Ustavni sud smatrao je da je Upravni sud, kad u upravnom sporu „odgovarajuće“ primjenjuje postupovna pravila Zakona o parničnom postupku, dužan uvažiti činjenicu da strukture parničnog postupka i upravnog spora nisu istovjetne. Ni uloge parničnih sudova, odnosno Upravnog suda u domaćem pravnom poretku također nisu istovjetne.

U konkretnom slučaju Upravni sud te činjenice nije u dostatnoj mjeri uvažio. On je na podnositeljevu tužbu neposredno primijenio pravilo o odbacivanju tužbe u parničnom postupku, ali je to pravilo parničnog postupka, promatrajući ga s aspekta Ustavom zaštićenog prava na pristup sudu, proizvelo u upravnom sporu nerazmjerne učinke za podnositelja u odnosu na cilj koji se želio postići. S t o g a je Ustavni sud na temelju prethodne analize zaključio:

„19. Dosljedno tome, Ustavni sud ocjenjuje da je Upravni sud svojim zaključkom - koji se temelji na posebno strogoj konstrukciji postupovnog pravila preuzetog iz parničnog postupka - da ne ispituje prethodno opisane slučajeve u meritumu, odnosno da tužbe a limine odbacuje, u svim istovrsnim slučajevima nerazmjerno umanjio samu bit prava na pristup sudu, koje je dio ustavnog prava na pravično suđenje zajamčenog člankom 29. stavkom 1. Ustava.“91

Drugim riječima, Ustavni sud utvrdio je ne samo povredu same biti podnositeljevog prava na pristup sudu već je utvrdio da je Upravni sud i u svim istovrsnim slučajevima nerazmjerno umanjio samu bit prava na pristup sudu kao dio prava na pravično suđenje.

Ukratko, na kraju ovog dijela rada, može se zaključiti da tek kada je riječ o neprihvatljivim pravnim stajalištima redovnih i specijaliziranih sudova o

90 V. Sotiris i Nikos Koutras ATTEE protiv Grčke (2000.), § 22. Usp. Beleš protiv Češke (2002.), § 62.

91 V. odluku Ustavnog suda broj: U-III-1/2009 od 3. studenoga 2010. (Narodne novine broj 126/10. i www.usud.hr). I u odluci broj: U-III-4374/2005 od 15. siječnja 2011. (Narodne novine broj 18/11. i www.usud.hr). Ustavni sud utvrdio je da je Upravni sud svojim pravnim stajalištem nerazmjerno umanjio tužiteljima samu bit prava na pristup sudu, utvrdiviši da kada bi se prihvatilo stajalište Upravnog suda da odluka Povjerenstva nije upravni akt, tada bi predmeti vezani uz ostvarivanje statusa hrvatskog branitelja iz Domovinskog rata djelatnika Ministarstva pravosuđa iz sustava izvršenja sankcija, načelno bili izuzeti iz kontrole zakonitosti u upravnom sporu. Time bi i sve stranke u navedenim postupcima ostale bez ikakve sudske zaštite, što je protivno temeljnim načelima na kojima je ustrojen ustavni poredak Republike Hrvatske. Navedeno stajalište Ustavni sud potvrdio je u odluci broj: U-III-3937/2011 od 14. prosinca 2011. (Narodne novine broj 1/12. i www.usud.hr), utvrdivši da je podnositelj bio nerazmjerno onemogućen u svom ustavnom pravu na pristup sudu, jer mu je rješenjem Upravnog suda odbačena kao nedopuštena tužba podnesena protiv Odluke o raspodjeli CEMT godišnjih dozvola uz obrazloženje kako akt koji se osporava tužbom nije upravni akt. V. i odluku Ustavnog suda broj: U-III-6070/2010 od 30. lipnja 2011. (Narodne novine broj 91/11. i www.usud.hr) u kojoj je Ustavni sud utvrdio da je „zbog formalističkog pristupa, izostala zajamčena (stvarna i sadržajna) sudska kontrola zakonitosti pojedinačnih upravnih akata koju vrši Upravni sud, a ujedno je takvom odlukom podnositelju nerazmjerno umanjena sama bit prava na pristup sudu“. 
pretpostavkama za podnošenje pravnih sredstava sudu, a koja stajališta sprečavaju podnositelje pristupu sudu na takav način ili do takve mjere da time bude narušena sama bit „prava na sud“, Ustavni sud će intervenirati kako bi zaštitio ustavno pravo na pristup sudu u pravnom sustavu Republike Hrvatske.

\section{ZAKLJUČNE NAPOMENE}

Ustavni je sud u okviru svoje nadležnosti značajno pridonio jačanju demokracije, vladavine prava i zaštiti ljudskih prava u Republici Hrvatskoj, nastojeći pri tome aktivno usvojiti visoke standarde Europskog suda u zaštiti ljudskih prava. U svojoj praksi vezanoj uz zaštitu ljudskih prava i temeljnih sloboda Ustavni sud, kao i strasbourški sud, najviše se bavi pravom na pravično suđenje.

U radu je razmotren dosadašnji razvitak prakse Ustavnog suda u odnosu na različite aspekte prava na pravično suđenje. Posebno je analizirana praksa u odnosu na pravo na pristup sudu jer je to osnovno pravo koje omogućuje korištenje ostalih jamstava propisanih člankom 29, stavkom 1. Ustava. Fokus je prvenstveno stavljen na odluke u kojima je Ustavni sud utvrdio povredu prava na pristup sudu zbog neprihvatljivih pravnih stajališta sudova.

Analiza dana u ovom radu pokazuje da Ustavni sud u zaštiti prava na pravično suđenje, a s tim u vezi i prava na pristup sudu, polazi od sljedećih načelnih pravnih stajališta:

Pravo na pravično suđenje, zajamčeno člankom 29, stavkom 1. Ustava, uvijek mora biti tumačeno u svjetlu vladavine prava, najviše vrednote ustavnog poretka Republike Hrvatske, kojoj je načelo pravne sigurnosti jedan od temeljnih aspekata: ono zahtijeva da sve stranke imaju djelotvorno pravno sredstvo pred domaćim sudovima koje im omogućuje da brane svoja prava.

Važan aspekt prava na pravično suđenje jest pravo na pristup sudu inherentno „pravu na sud“. Ostvarenje prava na pristup sudu omogućuje korištenje ostalih jamstava propisanih člankom 29, stavkom 1. Ustava, jer kada ne bi bilo jamstva prava na pristup sudu, značajke koje sudski postupak opisuju kao pošten i brz uopće ne bi imale nikakvu vrijednost ako sudski postupak ne bi započeo. Kako čitav sustav procesnih prava iz članka 29. Ustava počiva na ideji djelotvorne pravne zaštite, to je moguće samo u slučaju da ta zaštita bude i omogućena.

Pravo na pristup sudu nije apsolutno već je podvrgnuto ograničenjima, osobito kad je riječ o zakonskim pretpostavkama koje se tiču dopuštenosti ulaganja pravnih sredstava. Međutim, ograničenja ne smiju umanjiti pristup sudu na takav način ili do takve mjere da time bude narušena sama bit „prava na sud“. Stoga 
svako ograničenje mora biti ustanovljeno zakonom, mora imati legitimni cilj te mora postojati razuman odnos razmjernosti između ograničenja i cilja koji se tim ograničenjem želi postići.

Način na koji se primjenjuje članak 29, stavak 1. Ustava ovisi i o posebnim obilježjima sudskog postupka o kojemu je riječ. Naime, osim što se cjelokupni postupak u kojem se odlučuje o nečijem pravu ili obvezi mora sagledavati kao jedinstvena cjelina, važno mjesto u ispitivanju prihvatljivosti nametnutih ograničenja ustavnom pravu na pristup sudu zauzima i uloga pojedinog suda $\mathrm{u}$ domaćem pravnom poretku, odnosno posebna obilježja postupka o kojem je riječ, zbog čega je potrebno uvijek uzimati u obzir i ulogu koju viši sudovi imaju u tom postupku.

Na kraju, valja zaključiti da Ustavni sud - radi zaštite i promicanja ljudskih prava zajamčenih člankom 29 , stavkom 1. Ustava, a osobito prava na pristup sudu, uvažavajući činjenicu da ono nije apsolutno i da je podložno propisanim ograničenjima-smatra da pravo na pristup sudu uvijek mora biti stvarnoi djelotvorno, a ne teorijsko ili prividno. Drugim riječima, pravo na pristup sudu pojedincu mora biti zajamčeno ne samo formalno u zakonodavstvu Republike Hrvatske, nego se mora omogućiti da se ono stvarno i ostvari u svakom pojedinačnom slučaju.

\section{Literatura}

Belajec, V.: „Ustavne osnove za podnošenje ustavne tužbe“, Ustavni sud u zaštiti ljudskih prava - interpretativna uloga Ustavnog suda, Organizator, Zagreb, 2000., str. 97113.

Bačić, Arsen: „Ustav Republike Hrvatske i najviše vrednote ustavnog poretka“, Zbornik radova Pravnog fakulteta u Splitu (Online), 2012,. Vol. 49, br. 1, str. 1-21, http://www. pravst.unist.hr/dokumenti/zbornik/2012103/zb201201_001.pdf

Crnić, J.: Vladavina Ustava - zaštita sloboda i prava čovjeka i građanina ili kako pokrenuti postupak pred Ustavnim sudom Republike Hrvatske, Informator, Zagreb, 1994.

De Salvia, M.: „Execution of the Judgements of the European Court of Human Rights: Legal Nature of the Obligations of the States and European Supervision of National Legislative Choices“, The Status of International Treaties on Human Rights, Venice Commission, Collection Science and technique of democracy, No. 42., Strasbourg: Council of Europe Publishing, September 2006.

Galić, A., Đerđa, D.: „Žalba u upravnom sporu“, Odvjetnik, Zagreb, 2014., br. 5-6, str. 12-30. 
Grdinić, E.: „Pravo na pošteno suđenje u postupcima građanskopravne prirode zajamčeno čl. 6. st. 1. Europske konvencije za zaštitu ljudskih prava i temeljnih sloboda“, Hrvatska pravna revija, 2005. Vol. 5, br. 9, str. 7-16.

Grdinić, E.: „Opće jamstvo poštenog suđenja u kaznenim postupcima i presumpcija nedužnosti prema članku 6. stavcima 1. i 2. Konvencije za zaštitu ljudskih prava i temeljnih sloboda“, Hrvatska pravna revija, 2006., Vol. 6, br. 1, str. 7-17.

Iličić Topolovec, S.: Pravičan postupak iz članka 6. stavka 1. Europske konvencije za zaštitu ljudskih prava i temeljnih sloboda - građanskopravni aspekt, magistarski rad, Pravni fakultet Sveučilišta u Zagrebu, Zagreb, 2006.

Koprić, I.: „Europski standardi i modernizacija upravnog sudovanja u Hrvatskoj“, Europeizacija upravnog sudovanja u Hrvatskoj, Institut za javnu upravnu, Zagreb, 2014., str. 12-34.

Krapac, D: „Pretpostavke za pokretanje i vođenje ustavnosudskog postupka zaštite individualnih ustavnih prava i sloboda: Pravni okviri i stvarne granice (,procesnost“) hrvatskog modela ustavne tužbe“, Hrvatsko ustavno sudovanje de lege lata $i$ de lege ferenda, HAZU, Zagreb, 2009., str. 169-207.

Krapac, D.: Kazneno procesno pravo, Prva knjiga: Institucije, IV. izdanje, Narodne novine d.d., Zagreb, 2010.

Krapac, D.: Postupak pred Ustavnim sudom Republike Hrvatske - ustrojstvo $i$ proceduralni elementi ustavnog nadzora, Narodne novine, Zagreb, 2014.

Ljubić, D.: Ustavnosudska zaštita temeljnih ljudskih prava i sloboda - ustavna tužba (ustavna žalba), doktorska disertacija, Pravni fakultet Sveučilišta u Zagrebu, Zagreb, 2011.

Mahoney, P.: „Right to a Fair Trial in Criminal Matters under Article 6 E.C.H.R“, Judicial Studies Institute Journal, Judicial Studies Institute Dublin, 2004., Vol. 4, No. 2, str. 107-129.

Omejec, J.: Vijeće Europe i europska unija, institucionalni i pravni okviri, Novi informator, Zagreb, 2008.

Omejec, J.: Konvencija za zaštitu ljudskih prava i temeljnih sloboda u praksi Europskog suda za ljudska prava, Strasbourški acquis, Novi informator, Zagreb, 2013.

Pavišić, B.: Kazneno pravo Vijeća Europe, Golden marketing, Zagreb, 2006.

Potočnjak, Ž., Stresec, M.: „Europski sud za ljudska prava i Ustavni sud Republike Hrvatske u zaštiti ljudskih prava“, Hrvatsko ustavno sudovanje - de lege lata i de lege ferenda, Hrvatska akademija znanosti i umjetnosti, Zagreb, 2009., str. 209-246.

Ritossa, D.: „Elementi modela crime control i due process u odlukama tijela Europske konvencije za zaštitu ljudskih prava i temeljnih sloboda s obzirom na članak 6. stavak 1. Europske konvencije za zaštitu ljudskih prava i temeljnih sloboda“, Hrvatski ljetopis za 
Dr. sc. Duška Šarin: Aspekti prava na pravično suđenje - pravo na pristup sudu kroz jurisprudenciju... Zbornik radova Pravnog fakulteta u Splitu, god. 53, 3/2016., str. 729.-762.

kazneno pravo i praksu, Hrvatsko udruženje za kaznene znanosti i praksu, Zagreb, 2003., Vol. 10, br. 1, str. 75-107.

Rodin, S.: „Ustavni sud Republike Hrvatske i međunarodno pravo“, Zakonitost, časopis za pravnu teoriju i praksu, 1993., 47, broj 8/12, str. 578. - 587.

Rodin, S.: „The Constitutional Court of the Republic of Croatia and International Law“, Zetschrift für ausländisches öffentliches Recht und Völkerrecht (ZaöRV), Heidelberg Journal of International Law (HJIL), Max - Planck - Institut für ausländisches öffentliches Recht und Völkerrecht, 1995., Vol. 3, str. 783-799.

Rodin, S.: „Ustavnopravni aspekti primjene Europske konvencije za zaštitu ljudskih prava i temeljnih sloboda“, Zbornik Pravnog fakulteta u Zagrebu, Zagreb, 1998., Vol. 48, No. 1-2, str. 85-116.

Rozakis, C.: „The Right to a Fair Trial in Civil Cases“, Judicial Studies Institute Journal, Judicial Studies Institute Dublin, 2004., Vol. 4, No. 2, str. 96-106.

Smerdel, B., Sokol, S.: Ustavno pravo, IV. izdanje, Narodne novine d.d., Zagreb, 2009.

Sokol, S.: „Odnos Ustavnog suda i tijela sudbene vlasti“, Zbornik Pravnog fakulteta $u$ Zagrebu, Zagreb, 2000., Vol. 50, No. 1-2, str. 55-64.

Sokol, S.: „Ustavni sud Republike Hrvatske u zaštiti i promicanju vladavine prava“, Ustav kao jamac načela pravne države, Organizator, Zagreb, 2002., str. 15-28.

Šarin, D.: Nastanak hrvatskoga Ustava, Narodne novine, Zagreb, 1997.

Šarin, D.: „Konvencija za zaštitu ljudskih prava i temeljnih sloboda kroz odnos Europskog suda za ljudska prava i Ustavnog suda Republike Hrvatske na primjeru zaštite ljudskog prava na pristup sudu“, Pravni vjesnik, Pravni fakultet u Osijeku, Osijek, 2014., god. 30, br. 3-4, str. 77-100.

Šarin D.: „Ustavni sud Republike Hrvatske kao institucionalni zaštitnik ljudskih prava i temeljnih sloboda“, Zbornik Pravnog fakulteta u Splitu, Split, 2015., god 52., br. 3, str. 755-784.

Šarin, D.: „Pravo na pristup sudu u praksi Europskog suda za ljudska prava“, Pravni vjesnik, Pravni fakultet u Osijeku, Osijek, 2015., god. 31, br. 3-4, str. 267-296.

Triva, S., Dika, M.: Građansko parnično procesno pravo, VII. izdanje, Narodne novine d.d., Zagreb, 2004.

Uzelac, A.: „Hrvatsko procesno pravo i jamstvo pravičnog postupka iz Europske konvencije o zaštiti ljudskih prava“, Zbornik Pravnog fakulteta Sveučilišta u Rijeci, Rijeka, 1998., Vol. 19, Supplement, str. 1005-1030.

Uzelac, A.: „Pravo na pravično suđenje u građanskim predmetima: Nova praksa Europskoga suda za ljudska prava i njen utjecaj na hrvatsko pravo i praksu“, Zbornik Pravnog fakulteta u Zagrebu, Zagreb, 2010., Vol. 60, No. 1, str. 101-148. 
van Dijk, P., van Hoof, G. J. H.: “The margin of appreciation”, Theory and Practice of the European Convention on Human Rights, Haag, Kluwer Law International, 1998., str. 82-97.

Zupančić, B. M.: „On the Interpretation of Legal Precedents and of the Judgements of the European Court of Human Rights", The Owl of Minerva, Essays on Human Rights, Eleven International Publishing, Utrecht, 2008., str. 351-392.

\section{Propisi}

Ustav Republike Hrvatske (Narodne novine broj 56/90., 135/97., 113/00., 28/01., 76/10. i 5/14.)

Ustavni zakon o Ustavnom sudu (Narodne novine broj 99/99., 29/02. i 49/02. pročišćeni tekst)

Konvencija za zaštitu ljudskih prava i temeljnih sloboda (Narodne novine-Međunarodni ugovori, broj 18/97., 6/99. - pročišćeni tekst, 8/99. - ispr., 14/02. i 1/06.)

Haška konvencija o građanskopravnim aspektima međunarodne otmice djece (Narodne novine - Međunarodni ugovori, broj 4/94.)

Zakon o sudovima (Narodne novine broj 150/05., 16/07. i 113/08.)

Zakon o izmjenama i dopunama Zakona o sudovima (Narodne novine broj 153/09.)

Zakon o općem upravnom postupku (Narodne novine broj 47/09.)

Odluke i presude Europskog suda za ljudska prava navedene u radu

Odluke i rješenja Ustavnog suda Republike Hrvatske navedene u radu 


\section{CONSTITUTIONAL COURT JUDGE OF THE REPUBLIC OF CROATIA}

\section{Aspects of law in a fair trial- right to access the court through jurisprudence of the Constitutional Court of the Republic of Croatia}

The Constitutional Court of the Republic of Croatia in its practice is related to the protection of human rights and fundamental freedoms, which is entirely harmonised with the practice of the European Court of Human Rights, mostly deals with violation of the law on fair trial guaranteed by article 29 of the Constitutional Court of the Republic of Croatia. The development of the jurisprudence of the Constitutional Court of the Republic of Croatia to date is analysed concerning various aspects of law on fair trial with special emphasis on the right to access the courts. After determining aspects of the rights to a fair trial and the "right to court", the right to access the court or its limits is analysed. In particular the procedural presumptions of access to court such as the right to submit certain types of court applications (permission to sue), right to access the court through effective legal remedy (guaranteed right to appeal and the right to review) and the right to access the courts in certain court procedures. The focus is mainly on decisions in which the Constitutional Court of the Republic of Croatia has established violations of the mentioned rights due to unacceptable legal viewpoints of courts.

Key words: Constitutional Court in Croatia, Art. 29. of the Croatian Constitutition, aspects of law on fait trial, the right to acces the court 